\title{
Düşük Karbon Ekonomisine Geçme(me): İklim Değişikliği ve Enerji Politikaları Bağlamında Bir Bakış
}

Transition (or not) to Low Carbon Economy: The Overwiew in the Context of Climate Change and Energy Policies

Ferhunde Hayırsever TOPÇU1

Geliş tarihi: 09.05.2018, Kabul tarihi: 17.08.2018, Basım tarihi: 30.09.2018

\section{Özet}

Enerji sektöründen kaynaklanan sera gazı emisyonları toplam emisyonların yaklaşık üçte ikisini oluşturmaktadır. İklim değişikliği ile mücadelede düşük karbonlu ekonomiye geçiş önem kazanmaktadır. Ancak bu sürecin fosil yakıtların çıkarılması, üretimi, finansmanı, dağıtımı ve tüketimi çerçevesinde faaliyet gösteren ülke ve endüstrilere zarar verecek olması, bu ülke ve endüstrilerin direnç göstermesine neden olmaktadır. Diğer yandan ise iklim değişikliği ile mücadele yeni ekonomik kazanımlar ortaya çıkarmakta; karbonsuzlaştırma önerileri destek görmektedir. Bu çalışmanın amacı iklim değişikliği ve enerji politikaları bağlamında düşük karbon ekonomisine geçiş hedefini, bu hedefi destekleyen ya da geciktiren politika ve uygulamaları, literatür taraması yöntemiyle, Amerika Birleşik Devletleri, Avrupa Birliği ve Çin’in iklim ve enerji politikalarından elde edilecek örnekler çerçevesinde irdelemektir. Sonuç olarak fosil yakıt sektörünün belirleyiciliği devam etmekte; düşük karbon teknolojilerinin sağlayıcısı olarak gelişmiş ülke ve endüstriler tekel konumlarını sürdürmekte; emisyon ticareti gibi piyasa temelli mekanizmalar şirketler açısından yeni kazanç alanları olarak desteklenmekte; hem enerji hem de iklim adaleti açısından yoksunluklar ve sorunlar ortaya çıkmaktadır.

Anahtar Kelimeler: İklim değgisikliği, düsük karbon ekonomisi, enerji politikalar, enerji ve iklim adaleti

\begin{abstract}
Greenhouse gas emissions from the energy sector account for about two-thirds of total emissions. Due to the fight against climate change, transition to low carbon economy gains importance. However, the low carbon economy is likely to result in the resistance of these countries and industries to harming the countries and industries operating in the framework of the extraction, production, financing, distribution and consumption of fossil fuels. On the other hand, struggling with climate change presents new economic gains; decarbonization recommendation is supported. The aim of this study is to examine the objective of transitioning to a low carbon economy and the policies and practices that support or delay this goal in the context of climate change and energy policies by literature review of examples from the United States, European Union and China's climate and energy policies. As a result, the determination of the fossil fuel sector continues; the monopoly position of developed countries and industries as providers of low carbon
\end{abstract}

\footnotetext{
1 Akdeniz Üniversitesi İ.İ.B.F. Siyaset Bilimi ve Kamu Yönetimi Bölümü. Doç. Dr., https://orcid.org/0000-0001-9593-5500

hayirseverf@akdeniz.edu.tr
} 
technologies continues; market-based mechanisms such as emissions trading are supported as new earnings areas in terms of companies, both in terms of energy and climate justice, deprivations and problems arise.

Keywords: Climate change, low carbon economy, energy policies, energy and climate justice

\section{Giriş}

Hükümetlerarası İklim Değişikliği Paneli’nin (Intergovernmental Panel on Climate Change-IPCC) (2014) Beşinci Değerlendirme Sentez Rapori'na göre, son 30 yllın her 10 yll, 1850'den beri yaşanan en sıcak yıllar olmuştur. 19832012 arası Kuzey Yarımkürede son 1400 yllın en sıcak 30 yılı olmuştur. Kara ve okyanus yüzey sıcaklıkları $0.85 \mathrm{C}$ derece artmıstır. Son 20 yılda Grönland ve Arktik buz kütleleri hacim kaybetmeye devam etmiş, Kuzey Yarımkürede ilkbahar kar örtüsü azalmıştır. 1750 ve 2011 arasında kümülatif antropojenik karbondioksit $\left(\mathrm{CO}_{2}\right)$ emisyonlarının \%40’ı atmosferde kalmıştır. Okyanuslar salınan $\mathrm{CO}_{2}{ }^{\prime}$ in \%30'unu absorbe etmiştir, ancak bu okyanusların asitleşmesine sebep olmuştur. 1750 ile 2011 arasındaki $\mathrm{CO}_{2}$ emisyonlarının yaklaşı1k yarısı son 40 ylda gerçekleşmiştir (IPCC, 2014: 4). IPCC'nin ortaya koymuş olduğu senaryoya göre, küresel ortalama yüzey sıcaklık artışının 2016-2035 döneminde 1986-2005 dönemine göre, 0.3 ila 0.7 C derece arasında artacağ1 öngörülmektedir. 1850-1900 dönemine göre, 21. yüzyllın sonunda (2081-2100) ise küresel yüzey sıcaklığının 1.5 C dereceyi aşacağı ifade edilmektedir (IPCC, 2014: 10).

Aralık 2015'de Paris'te 21. Birleşmiş Milletler (BM) İklim Değişikliği Taraflar Konferansı toplanmış ve Paris Anlaşması kabul edilmiştir. Anlaşmanın temel amacı, bu yüzyılda küresel sıcaklık artışını $2 \mathrm{C}$ derece altında tutarak ve sıcaklık artışını $1.5 \mathrm{C}$ dereceye kadar sınırlandırmaya yönelik çabaları sürdürerek iklim değişikliği tehdidine karşı küresel cevab1 güçlendirmektir (UNFCC, 2017). Bu hedefin anlamı, ülkelerin şu an \%80'den fazla fosil yakıt kullandığı bir dünyanın çok ciddi anlamda başta kömür olmak üzere petrol ve doğal gazdan vazgeçmesi ve temiz enerji kullanımına geçmesi demektir (Karakaya, 2015).

BM İklim Değişikliği Çerçeve Sözleşmesi çerçevesinde emisyon azaltımı hedefleyen 187 ülkenin sunduğu Ulusal Katkı Beyanlarında, planlanan politikalarıyla yerkürenin 1sısının Anlaşmada öngörülen sınırın çok üstü olan 2.7 C dereceyi aşacağı öngörülmektedir. Dolayısıyla, mevcut çabaların yeterli olmadığı görülmekte ve asıl yapilması gerekenler bundan sonra daha çok önem arz etmektedir. Anlaşmada bu nedenle ülkelerin düzenli bir şekilde her beş yılda bir mevcut pozisyonlarını bilimin de desteğiyle gözden geçirmesi ve güçlendirmesi istenmektedir. Bu çerçevede, önümüzdeki yllar düşük karbonlu bir ekonomiye geçiş için ülkeleri daha fazla önlem almaya yönlendirecektir (Karakaya, 2015). 
Düşük karbonlu ekonomiye geçişte, fosil yakıtların kademeli olarak azalıımı, yerine yenilenebilir enerji kaynaklarının ikamesi; enerji verimliliğinin bir üretim ilkesi haline gelmesi; tüm tüketim alışanlıklarının değişmesi ve israfin bertaraf edilmesi ile ormanlaştırmanın hızlandırılmasını kapsayan çok yönlü bir süreçten söz edilmektedir.

Dünyada fosil yakıtlara dayalı enerji politikalarının hakim oluşu dikkate alındığında, gerek iklim değişikliğinin ortaya çıkışı gerek iklim değişikliği ile mücadele nedeniyle sorgulanan ve değişim beklenen politika alanlarının başında enerji politikaları gelmektedir. Enerji sektöründen kaynaklanan sera gazı emisyonları toplam sera gazı emisyonlarının yaklaşık üçte ikisini oluşturmaktadır ve bu sektörün karbondioksit emisyonları geçen yüzyılda daha da yüksek seviyelere ulaşmıstır. İklim değişikliği ile mücadele için enerji sektöründe etkili bir hareket şarttır (IEA, 2015: 20). Ancak birçok nedenle bu değişim henüz gerçekleşmiş değildir ve Paris Anlaşmasının süreç açısından etkisi de zamanla görülecektir.

Bu çalışmanın amacı iklim değişikliği ve enerji politikaları bağlamında düşük karbon ekonomisine geçiş hedefini, bu hedefi destekleyen ya da geciktiren politika ve uygulamaları, literatür taraması yöntemiyle, Amerika Birleşik Devletleri (ABD), Avrupa Birliği (AB) ve Çin’in iklim ve enerji politikalarından elde edilecek örnekler çerçevesinde irdelemektir. Bu amaçla çalışmada ilk olarak iklim değiş̧ikliği sorununun ortaya çıkış sürecinde karbon emisyonlarının etkisi ortaya konulacaktır. İkinci olarak düşük karbon ekonomisine geçme(me) süreci irdelenecektir. Bu bölümde iklim değişikliği politikalarına karşı çıkan ve/veya destekleyen enerji politikalarına ve sürecin yarattığı adalet sorunlarına yer verilecektir. Çalışmada $A B D, A B$ ve Çin'in iklim ve enerji politikalarından verilecek örnekler, çalışmanın sınırları dikkate alındığında, daha çok genel yönelimi ortaya koyabilecek nitelikte olacaktır.

\section{1. İklim Değişikliğinin Ortaya Çıkışında Karbon Emisyonları}

İklim değişikliğine neden olan karbon emisyonlarının artmasında fosil yakıt tüketimi belirleyici bir rol oynamaktadır. IPCC Sentez Raporìna (2014) göre, 1970 ile 2010 arasında toplam sera gazı emisyonlarındaki artısın yaklaşı1k \%78'i fosil yakıt tüketiminden ve endüstriyel süreçlerden kaynaklanmıştır. Küresel olarak ekonomik büyüme ve nüfus artışı fosil yakıt tüketiminden kaynaklanan $\mathrm{CO}_{2}$ emisyon artışlarının en önemli nedenleridir. 2000 ile 2010 arasında nüfus artışının katkısı önceki 30 yıla göre hemen hemen aynı kalmasına karşın, ekonomik büyümenin katkısı keskin bir şekilde artmıştır (IPCC, 2014: 5).

Dünyada 2014 yll itibariyle, toplam sera gazı emisyonlarında Çin ilk sırada yer alırken, onu ABD ve Avrupa Birliği izlemektedir (Tablo 1). Kişi başına düşen emisyon miktarında ise Kanada, ABD ve Rusya'nın kişi başına emisyonları dünya kişi başına emisyon ortalamasının iki katından daha 
fazladır (World Resources Institute, 2014). Çin'in 2014 yllında kişi başına emisyonları 6.2 tona ulaşırken, OECD ortalamalasının üçte biridir. Hindistan'ın kişi başına emisyonları 2014'de 1.6 tondur ve bu ABD'nin seviyesinin \%10’u, Çin'in \%25’idir (IEA, 2015: 28).

Tablo 1: Toplam Sera Gaz1 Emisyonlar1 (2014)

\begin{tabular}{|c|c|c|}
\hline & $\begin{array}{l}\text { Toplam Sera Gaz1 } \\
\text { Emisyonları } \\
\text { Kullanımı Değişikliği ve } \\
\begin{array}{l}\text { Ormancılık Hariç) } \\
\left(\mathrm{MtCO}_{2} \mathrm{e}\right)\end{array}\end{array}$ & $\begin{array}{l}\text { Toplam Sera Gaz1 } \\
\text { Emisyonları (Arazi } \\
\text { Kullanımı Değişikliği ve } \\
\begin{array}{l}\text { Ormancılık Dahil) } \\
\left(\mathrm{MtCO}_{2} \mathrm{e}\right)\end{array}\end{array}$ \\
\hline Çin & $11,911.71$ & $11,600.63$ \\
\hline $\mathrm{ABD}$ & $6,371.10$ & $6,319.02$ \\
\hline AB (28) & $4,053.66$ & $3,624.82$ \\
\hline Hindistan & $3,079.81$ & $3,202.31$ \\
\hline Rusya & $2,137.83$ & $2,030.14$ \\
\hline Japonya & $1,314.59$ & $1,322.05$ \\
\hline Dünya Toplam & $44,204.50$ & $47,350.94$ \\
\hline
\end{tabular}

Kaynak: World Resources Institute, 2017.

Sera gazı emisyonlarında bir diğer gösterge bir ülkenin tarihsel olarak toplam emisyonlarını tanımlayan kümülatif emisyonlardır. Bu rakamlar genellikle iklim değişikliği konusunda ülkelerin sorumluluklarını ayırt etmek için kullanılmaktadır, Bu ölçümler seçilen başlangıç tarihine ve kapsanan sektörlere göre önemli ölçüde değiş̧ebilmektedir (World Resources Institute, 2014). Tablo 2, Arazi Kullanımı Değişikliği ve Ormancılık (Land-Use Change and Forestry LUCF) dahil olmak üzere küresel emisyonları en yüksek olan on ülkenin 1850-2011 ve 1990-2011 dönemlerinde kümülatif emisyonlarını göstermektedir. 1850-2011 dönemi itibariyle bakıldığında, emisyonlarda en büyük ilk beş ülke ABD, AB, Çin, Rusya Federasyonu ve Japonya'dır. $\mathrm{Bu}$ ülkeler dünyada tarihsel olarak toplam sera gazı emisyonlarının üçte ikisini gerçekleştirmişlerdir. 1990 yılından 2011 yllına kadar olan dönem dikkate alındığında ise, emisyonların yaklaşı yarısının $\mathrm{ABD}$, Çin, $\mathrm{AB}$ ve Rusya Federasyonu olmak üzere sadece dört ülkeden kaynaklandığı görülmektedir. 
Tablo 2: Kümülatif sera gazı emisyonları (Dünya Toplamının Yüzdesi)

\begin{tabular}{|l|l|l|l|}
\hline & $\mathbf{1 8 5 0 - 2 0 1 1}$ & & $\mathbf{1 9 9 0 - 2 0 1 1}$ \\
\hline ABD & $\% 27$ & ABD & $\% 16$ \\
\hline Avrupa Birliği (28) & $\% 25$ & Çin & $\% 15$ \\
\hline Çin & $\% 11$ & Avrupa Birliği (28) & $\% 12$ \\
\hline Rusya Federasyonu & $\% 8$ & Rusya Federasyonu & $\% 6$ \\
\hline Japonya & $\% 4$ & Brezilya & $\% 5$ \\
\hline Hindistan & $\% 3$ & Endonezya & $\% 4$ \\
\hline Kanada & $\% 2$ & Hindistan & $\% 4$ \\
\hline Endonezya & $\% 1$ & Japonya & $\% 3$ \\
\hline Brezilya & $\% 1$ & Kanada & $\% 2$ \\
\hline Meksika & $\% 1$ & Meksika & $\% 2$ \\
\hline Dünyanın Geri Kalanı & $\% 17$ & Dünyanın Geri Kalanı & $\% 31$ \\
\hline
\end{tabular}

Kaynak: (World Resources Institute, 2014 verilerinden oluşturulmuştur).

\section{Düşük Karbon Ekonomisine Geçme(me)}

Genel olarak iklim değişikliğini azaltmak ve uyum sağlamak konusunda yaygın bir destek olmasına karşın, bu hedefi başarmak için getirilen öneriler, farklı tür politik tercihler olduğundan, uyumsuz hatta çatışmalı olabilmektedir (Phelan vd., 2013: 201). Bu nedenle bir tarafta düşük karbon ekonomisine geçiş desteklenirken, diğer tarafta aksi yönde girişimler de varlığını artırarak sürdürmeye devam etmektedir.

BM İklim Değişikliği Çerçeve Sözleşmesi ve Kyoto Protokolü müzakerelerinde, bağlayıcı ve sayılaştırılmış emisyon azaltım yükümlülüklerinin tespit edilmesi, gelişmiş ya da gelişmekte olan ülkelerin yükümlülüklerinin belirlenmesi ya da ülkelerin indirim yükümlülügü dışında tutulması gibi önerilerde çatışma ve uyuşmazlıklar görülebilmektedir. Emisyon yükümlülüklerindeki söz konusu farklılıkların bir tarafta ülkelerin sera gazlarının artmasındaki tarihsel sorumlulukları ve ortak fakat farklılaştırılmış sorumluluk ilkesi gereği olduğu bilinmektedir. Ancak diğer 
tarafta Çerçeve Sözleşme ve Kyoto Protokolü'nün getirmiş olduğu sayısal emisyon azaltım yükümlülüklerinin sorunun ortadan kaldırılması için gereken düzeyin altında olması, 1990 baz yılının seçilmesinin objektif bir tercihten çok moral bir seçim olması (Mazlum, 2008), Kyoto Protokolü'nün ikinci döneminde gönüllü emisyon taahhütlerinin tercih edilmesi, sadece ortak fakat farklılaştırılmış sorumluluk ilkesi ile açılanabilir değildir. Devletlerin farklı emisyon tahhütleri düşük karbon ekonomisine geçme ve/veya geçmeme yönündeki iradelerini de göstermektedir.

Bu çalışmada örnek alınan Avrupa Birliği iklim müzakerelerinde daha sıkı hedefleri ile liderlik rolünü üstlenirken, ABD Kyoto Protokolü'ne taraf olmamış, Çin için ise Kyoto Protokolü emisyon sınırlaması getirmemiştir.

Avrupa Komisyonu, Lizbon Stratejisi'nden yola çıkarak ve mali kriz ile ekonomik bunalımla oluşan yeni küresel konjonktürü dikkate alarak, akıllı, çevreci ve kapsayıcı büyüme için "Avrupa 2020" adlı yeni bir stratejiye önayak olmuştur. Bu yeni stratejide 2020 yll için AB iklim ve enerji hedefleri, sera gazı salımının 1990 yılına kıyasla en az \%20, şartlar elverişli ise $\% 30$ oranında azaltılması; AB'nin enerji tüketiminde yenilenebilir enerjinin payının \%20'ye yükseltilmesi ve $\% 20$ oranında enerji verimliliği sağlanmasıdır (Akses, 2014: 32; Akbaş ve Apar, 2010: 3). İklim değişikliği ve temiz ve verimli enerji kullanımı alanında "Kaynakları Verimli Kullanan Avrupa" (Resource Efficient Europe) girişimi ile kaynaklarını verimli kullanan düşük karbonlu bir ekonomiye dönüşüm amaçlanmaktadır. Bu kapsamda, Birlik düzeyinde, AB'nin finansal araçları (yapısal fonlar ve topluluk programları vb.) ile birlikte piyasa tabanlı araçların (emisyon ticareti ve enerji vergilendirilmesi vb.) en iyi şekilde kullanılması için çerçeve koşulların iyileştirilmesi öngörülmüştür (Akbaş ve Apar, 2010: 5).

ABD iklim değişikliği politikasında $A B$ ülkelerine göre yavaş hareket etmektedir. Clinton yönetimi Kyoto görüşmelerinde önemli bir rol oynamış, ancak Protokolü Kongre onaylamamıştır. 2002'de George W. Bush ülkedeki sera gazı yoğunluğunu 2002-2012 dönemi boyunca \%18'e çekmeyi bir hedef olarak belirlemiştir. Otomobillerde yakıt verimliliğinin artırılması gibi bazı tedbirlerle ekonominin karbonsuzlaşması yönündeki tedbirler işletilse de, bunlar iklim değişikliğine yönelik endişelerin değil, büyük ölçüde enerji güvenliği ile ilgili düşüncelerden kaynaklanmıştır. 2003 tarihli John McCainJoseph Lieberman İklim Yönetimi Yasası önerisi, 2007 tarihli LiebermanWarner önerisi kabul görmemiştir (Giddens, 2013: 129-130).

ABD'de Haziran 2009'da Demokratların kontrolü altındaki Temsilciler Meclisi Amerikan İklim ve Enerji Güvenliği Yasası'nı (American Climate and Energy Security Act) kabul etmiştir. "Waxman-Markey Önerisi” olarak bilinen Yasa emisyon izin ticareti öngörüyordu. AB’ninkine benzer olan Amerikan emisyon ticaret programı üçüncü evresindedir ve sera gaz1 emisyonların 2005 düzeyine göre, 2012'ye kadar \%3, 2020’ye kadar \%17, 
2030'a kadar \%42, 2050'ye kadar \%83 oranında azaltmayı hedefliyordu. Bu nedenle açıkça AB 2020 Paketi ve Amerikan İklim ve Enerji Güvenliği Yasası arasında stratejik hedefleri ve bunların araçları konusunda benzerlikler vardır. Ancak AB'deki genel uzlaşmaya karşın, Amerikan Yasası Senato'dan geçmesi için gereken uzlaşmayı elde edememiştir. Başkan Obama'nın ikinci döneminde, Amerikan Kongresi'nin politik çoğunluğunun bölünmesinin yanı sıra küresel ekonomik resesyon ve ulusal bütçe problemleri diğer politik girişimleri savunmayı da zorlaştırmıştır. Bu nedenle kapsamlı bir federal enerji ve iklim yasasının kabulü mümkün olmamıştır (Heras, 2013: 20-21).

Kapsamlı bir iklim değişikliği politikası geliştirme sorumluluğu olan bir ülke olarak ABD'de ulusal düzeyde bir şey yapılmamış olmasının Giddens'a (2013: 131) göre üç nedeni vardır: Birinci neden Amerikan Anayasasında başkanın iç politikayla ilgili tüm meselelerde Kongre ile müzakere etmesini gerektiren güçler ayrllı̆ğdır. İkincisi güçlü lobilerin tek tek kongre üyeleri üzerinde muazzam bir ağırlığa sahip olma becerisidir. Bu noktada fosil yakıt ve diğer doğal maddeleri işleme endüstrileri güçlü bir örgütlenme mekanizmasına ve siyaset üzerinde etkiye sahiptirler. Üçüncü neden iklim değişikliğinin politik düzlemde Demokratlar ile Cumhuriyetçiler arasında kutuplaştırlmış bir konu haline gelmesidir. Özellikle Cumhuriyetçi Parti iklim değişikliğinin nedeninin insan faaliyetleri olduğunu reddetmektedir. ${ }^{2}$

Kongre'nin iklim değişikliği konusundaki hareketsizliği eyalet ve yerel düzeyde kabul edilen iklim değişikliği eylem planları, sera gazı emisyon hedefleri, sera gazı araç emisyon standartları, yenilenebilir enerji standartları, kamusal fonlar ve ölçüm programları, bina etkinlik standartları, sera gazları emisyon izinleri ticaret programları gibi çeşitli politika önerileri ile doldurulmaktadır (Engel, 2015: 455). Günümüzde yaklaşık 40 eyaletin iklim eylem planı vardır ve 20'sinin eyalet düzeyinde emisyon hedefleri vardır (Heras, 2013: 22-23).

ABD'de Haziran 2014'de Çevresel Koruma Ajansı (Environmental Protection Agency -EPA) tarafindan yayımlanan Temiz Enerji Planı (Clean Power Plan) eyaletler düzeyinde farklılaşan karbon azaltım hedefleri belirlemiştir. Bu hedefler Kentucky, West Virginia ve North Dakota gibi kömüre dayalı eyaletlerde minimal azaltım; Washington, Kaliforniya ve New Jersey gibi daha temiz enerjinin kullanıldığı eyaletlerde daha yüksek azaltım hedefleri içermektedir (Engel, 2015: 452). Planın tüm eyaletler için öngördüğü hedef azaltım oranları toplandığında, EPA'nın tahminlerine göre,

\footnotetext{
22012 Cumhuriyetçi Başkan adayı Mitt Romney bilimsel belirsizliğin varolduğunu ve emisyon ticareti politikasının ekonomi için felaket olacağını ifade etmiştir. 2011 kamuoyu yoklamalarına göre, Amerikalıların \%64’ü iklim değişikliğinin olduğuna inanmakta, ancak sadece \%47'si buna insan faaliyetlerinin sebep olduğunu düşünmektedir. Kasım 2008'de bu oranlar sirasiyla $\% 71$ ve $\% 57$ idi (Vezirgiannidou, 2013: 596).
} 
elektrik üreten sektörden kaynaklanan toplam emisyonların 2030'da 2012 y1l seviyesinden \%30 azalacağ1 öngörülmektedir (Engel, 2015: 458).

Çin ise son yıllarda iklim değişikliği ve temiz enerji ile ilgili konulara daha çok dikkat etmektedir. Çin 2007'de Ulusal İklim Değişikliği Programı yayımlayan ilk gelişmekte olan ülkedir (Heras, 2014: 23). Çin'de bu konularda yayımlanan ilk en kapsamlı çerçeve yasa ve uygulama programı 2011'de kabul edilen ve 2011-2015 dönemi için ekonomik kalkınma stratejilerini ortaya koyan 12. Beş Yıllık Plan (BYP)'dı. En çarpıcı özelliği ilk kez planın hem enerji hem de iklim değişikliği ile ilgili belirli sınırlama hedefleri ortaya koymasidir. Plan'da temel hedefler, toplam enerji kullanımında fosil yakıt olmayan enerji kaynaklanının payında \%11.4 artış; karbon yoğunluğunda (GSMH başına karbon emisyonları) \%17 azalma; enerji yoğunluğunda (GSMH başına enerji tüketimi) \%16 azalma idi (Heras, 2014: 24). 2016-2020 dönemine ilişkin hazırlanan 13. Beş Yıllık Kalkınma planına göre ise, Çin GSMH başına düşen enerji tüketimini 2015 yılına kıyasla \%15 azaltmayı ve yine aynı dönemde karbon yoğunluğunu \%18 oranında azaltmayı hedeflemektedir. Planda rüzgar, güneş ve jeotermal enerji kapasitesinin artırılması, enerji tüketiminde 4,3 milyar ton kömüre eşdeğer bir azaltım sağlanması, kömür için eski madenlerin kapatılıp şirketlerin birleştirilmesi yoluyla kapasitenin 1 ton azaltılması, önümüzdeki üç yıl için yeni kömür madenlerinin yasaklanması gibi öneriler dikkat çekmektedir (Pashley, 2016).

2015’te kabul edilen Paris Anlaşması öncesi 2013 yılında yapılan Varşova Konferansı'nda taraf devletler Niyet Edilen Ulusal Katkı Beyanı (Intended Nationally Determined Contribution-INDC) sunmaya davet edilmişler ve çoğu ülke taahhütlerini bildirmişlerdir. Bu çerçevede zorunlu emisyon taahhütlerinin yokluğunda, $\mathrm{AB}, \mathrm{ABD}$ ve Çin'in belirlemiş olduğu hedefler Tablo 3'de gösterilmektedir. Buna göre, Avrupa Birliği 1990 yllına göre emisyonlarda \%40 gibi kesin ve önemli bir azaltma hedeflemektedir. ABD sera gazlarının 2005 seviyesine göre \%26-28’lik bir azalmayı içeren daha geniş bir ekonomik hedef tanımlamakta ve bunun için en iyi çabay1 göstermeyi taahhüt etmektedir. Çin ise 2030 yllına kadar $\mathrm{CO}_{2}$ emisyonları için belirgin bir hedef koymazken, ulusal milli gelir başına sera gazı emisyon düzeyini 2005 seviyesinin $\% 60$ ila 65 oranında azaltmayı taahhüt etmektedir. Ayrıca fosil olmayan yakıtların oranını ve orman hacmini artırma, iklim değişikliğine uyum gibi diğer hedeflere de yer vermektedir. 


\section{Tablo 3: Avrupa Birliği, ABD ve Çin'in Ulusal Katkı Beyanları (INDC), 2015}

\begin{tabular}{|c|c|c|}
\hline $\begin{array}{l}\text { Ülke ve } \\
\text { INDC } \\
\text { Verme } \\
\text { Tarihi }\end{array}$ & INDC Özeti & Azaltım Katkı Tipi \\
\hline $\begin{array}{l}\text { Avrupa } \\
\text { Birliğgi } \\
6.3 .2015\end{array}$ & $\begin{array}{l}\text { AB ve üye ülkeler } 2030 \text { yllına kadar sera gazı } \\
\text { emisyonlarını } 1990 \text { düzeyine göre en az } \% 40 \\
\text { oranında azaltmayı içeren bağlayıcı hedefini } \\
\text { taahhüt etmektedir. }\end{array}$ & $\begin{array}{l}\text { Sera gazı hedefi, baz } \\
\text { y1lı hedefi (baz y1lı } \\
\text { emisyonlarında } \\
\text { kesin azaltma) }\end{array}$ \\
\hline $\begin{array}{l}\text { ABD } \\
31.3 .2015\end{array}$ & $\begin{array}{l}\text { ABD sera gazı emisyonlarını } 2025 \text { 'de } 2005 \text { 'deki } \\
\text { seviyesinden } \% 26-28 \text { azaltmayı içeren geniş } \\
\text { ekonomi hedefini başarmayı ve emisyonlarını } \\
\% 28 \text { oranında azaltmak için en iyi çabayı } \\
\text { göstermeyi amaçlamaktadır. }\end{array}$ & $\begin{array}{l}\text { Sera gazı hedefi, baz } \\
\text { yılı hedefi }\end{array}$ \\
\hline $\begin{array}{l}\text { Çin } \\
\text { 30.6.2015 }\end{array}$ & $\begin{array}{l}\text { Çin ulusal olarak } 2030 \text { yılına kadar aşağıdaki } \\
\text { faaliyetleri belirlemiştir: } \\
\text { - } 2030 \text { yılında } \mathrm{CO}_{2} \text { emisyonlarının en iyi } \\
\text { düzeyini başarmak ve daha önce bunu başarmak } \\
\text { için en iyi çabayı göstermek; } \\
\text { - Ulusal Milli Gelir başına } \mathrm{CO}_{2} \text { emisyonlarını } \\
2005 \text { düzeyinden \%60 ila } 65 \text { oranında azaltmak; } \\
\text { - Temel enerji tüketiminde fosil olmayan } \\
\text { yakıtların oranını yaklaşı \% } 00 \text { artırmak; } \\
\text { - Orman stok hacmini } 2005 \text { düzeyinden } \\
\text { yaklaşık } 4.5 \text { milyar metre küp artırmak. } \\
\text { Ayrıca Çin kentler, kıyılar ve ekolojik olarak } \\
\text { hassas alanların yanı sıra tarım, ormancılık ve su } \\
\text { kaynakları gibi temel alanlarda iklim değişikliği } \\
\text { risklerine karşı etkili bir şekilde savunma } \\
\text { mekanizması ve kapasitelerini artırarak iklim } \\
\text { değişikliğine aktif bir şekilde uyum sağlamaya ve } \\
\text { erken uyarı, acil müdahale sistemleri ve afet } \\
\text { önleme ve azaltma mekanizmalarını } \\
\text { güçlendirmeye devam edecektir. }\end{array}$ & $\begin{array}{l}\text { Sera gazı hedefi- } \\
\text { sera gazı dişı hedefi; } \\
\text { yoğunluk hedefi ve } \\
\text { yol haritası hedefi }\end{array}$ \\
\hline
\end{tabular}

Kaynak: (World Resources Institute, 2016)

$\mathrm{Bu}$ çerçevede ülkeler arasında hem baz yllının hem de hedeflerin değişmesi, $A B D$ ve Çin'in daha esnek hedefler belirlemesi, $A B D$ ve Çin'in en iyi çabayı göstermeyi taahhüt etmesi, enerji ile ilgili stratejilerin içeriğinin 
ve etkilerinin farklı ve çatışmalı olabileceğini bir kez daha göstermektedir. Ayrıca ülkelerin kendi içinde de politikalar zaman içinde değişebilmektedir. ABD'de Başkan Donald Trump'ın göreve gelmesiyle gözlenen değişim bunun açı örneğidir. İzleyen bölümde iklim değişikliği politikalarına karşı koyma ve destekleme süreci ayrı ayrı irdelenecektir.

\section{1 İklim Politikalarına Karşı Çıkı̧̧}

İklim değişikliği karbon-temelli ekonomik büyümenin uzun vadeli bir sonucudur. Sera gazları emisyonlarını azaltmanın birçok yolu geleneksel enerji sektörünün enerji arzının güvenliğini sağlamak gibi "çekirdek" hedeflerine yabancıdır. Birçok ülkenin güvenli, ödenebilir enerji sunumunda politik ve kurumsal çıkarları vardır. Bu durum hükümette, kamusal alanda ve özel sektörde enerji karar vericilerini güçlü aktörler yapmaktadır; oysa iklim açısından aynı şey geçerli değildir (Bazilian vd, 2010: 253- 254). ${ }^{3}$

Kamu ve özel sektörün kapasitesi ve etki derecesi ülkeler arasında ve zaman içinde değişebilmektedir. Enerji politikaları konusunda Avrupa Birliği’nde önemli girişimler ulusüstü düzeyde, ABD’de federal düzeyde ve eyalet düzeyindedir. Çin'de söz konusu politik açılımlar ulusal düzeyde parti ve hükümetten gelmektedir (Heras, 2014: 27).

2. Dünya Savaşı'nı izleyen dönemde enerji her yerde rağbet gören devlet planlamasının klasik uygulama alanlarından biri olmuştur. Savaş koşullarında enerji güvenliği temel mesele haline gelmiş ve hükümetler bu gelişmeye bağl1 olarak süreci kontrol etmeye başlamışlardır. Kömür madenciliği yaygın olarak millileştirilirken, ellilerde ve altmışlarda nükleer enerjiye dönülmesi her yerde devlet eliyle gerçekleşmiştir. Devlet seksenlerden itibaren geri plana çekilerek, piyasanın kontrol dişında kalmasına imkan tanımıştır. Yetmişlerin sonundan itibaren enerji alanında dünya genelinde rekabet ortamı oluşmuş; enerji piyasalarının özelleştirilmesi ve serbestleştirilmesi kural haline gelmiştir. Ancak söz konusu tedbirler giderek başarısız olmuşlardır. 2000'lerin başından itibaren "yeni bir enerji paradigması" olarak ifade edilen yaklaşım tarzı ortaya çıkmıştır. Yeni yaklaşımda petrol ve gazda gerçekleşen fiyat artışları, ulusal enerji kaynaklarına geri dönüş, tesislerin modernizasyonu, geleceğe dönük yatırımlar, diş politikanın enerji güvenliğindeki öneminin kabul edilmesi, iklim değişikliğinin sınırlandırılmasına dönük mücadele ile enerji politikalarının bütünleștirilmesi ihtiyacına dönük farkındalık etkili olmaktadır. Enerji piyasalarına bir kez daha müdahale edilmeye başlanmıştır (Giddens, 2013: 67-69). Bir tarafta deregülasyon politikaları ile rekabetçi piyasa şartları oluşurken, diğer tarafta

\footnotetext{
${ }^{3}$ Hükümet sistemlerinde iklim değişikliği genelde çevre bakanlığına tahsis edilmekte, bu bakanlık da hükümeti etkileme noktasında pek güçlü bir konumda olamamaktadır. Bu tarz bakanlıklar da çoğunlukla ulaşım, enerji, sağlık vb. bakanlıklardan ayrı bir işleyişe sahiptir (Giddens, 2013: 170).
} 
küresel enerji piyasalarında deregüle faaliyetlerin yoğunlaşması ile arz talep mekanizması içinde serbest piyasa koşullarında ortaya çıkan riskin yönetilmesi adına düzenleyici ve denetleyici otorite olarak özerk kamu kurumlarının serbestleşmenin önünde yol gösterici olarak regülasyon politikaları yaygınlık kazanmışır (Turgut, 2015: 100, 109).

Serbestleşen piyasa şartları çerçevesinde, belirli amaçlar için enerji paylaşımı, kullanımı ve tüketimi kararları çoğunlukla kamunun gözü önünde ve demokratik forumlarda olmaz. Ticari gizlilik ya da jeo-stratejik hassasiyetler gibi nedenlerle enerji yönetimine ilişkin sorularda kamusal katılım ve tartışma geleneksel olarak zayıftır. Kamusal katılım teşvik edilse bile, bu durum paydaşları sonuçları şekillendirmek için dahil etmekten çok, varsayımların kamusal tartışmaya açık olmadığı model ve tahminlere dayalı sınırlı seçeneklere dayanan danışma aracılığıyla sıklıkla önceden alınmış kararların meşrulaştırılmasına hizmet etmektedir. Enerji sunumu özel sektörde, taraflar da güçlü seçkinler ya da çokuluslu şirketler olduğunda bunları düzenlemek daha zor olacaktır. Devletler de özellikle çoktaraflı kalkınma bankalarının gözetiminde reform programlarının bir parçası olarak sektörü kontrolden feragat etmekte ya da sektörü liberalize etmeleri gerekmektedir. Ayrıca düşük karbona geçişte de kamusal kaynaklar ihtiyaç duyulan ölçekte fonların sağlanmasında yetersizdir ve emisyonları aşağıya çekmek için önemli birçok yeni teknolojiyi ve üretim süreçlerini özel sektör kontrol etmektedir (Newell ve Mulyaney, 2013: 135-136).

Özellikle fosil yakıtların ağırlı̆̆ı dikkate alındığında, düşük karbon ekonomisini başarmanın fosil yakıtların çıkarılması, üretimi, finansmanı, dağıtımı ve tüketimi çerçevesinde faaliyet gösteren ülke ve endüstrilere zarar verecek olması, bu ülke ve endüstrilerin direnç göstermesine neden olmaktadır (Vezirgiannidou, 2013: 603).

2015 yllı verileri itibariyle petrol, dünya enerji talebinin \%32,6'sını, doğal gaz ise \%23,7'sini karşılamıştır. 2014 yllında, 88,7 milyon v/g olarak kaydedilen petrol üretimi, 2015 yllinda, \%2,8 artarak 91,2 milyon v/g'e yükselmiştir. Bu üretimin \%30'luk bölümü Orta Doğu'da gerçekleşmiştir. Üretim alanında dikkati çeken önemli husus, Kuzey Amerika'da gerçekleşen üretimin (19,4 milyon v/g), Avrupa ve Avrasya'da gerçekleşen üretimi (17,3 milyon $\mathrm{v} / \mathrm{g}$ ) geride bırakmasıdır. ABD'de yatay sondaj ve hidrolik çatlatma gibi konvansiyonel olmayan yöntemlerle çıkarılan petrolün son yıllarda hızlı bir şekilde artması, küresel ölçekte petrol piyasasında arz talep dengelerini değiştiren bir teknolojik gelişme olarak değerlendirilmektedir. 2015 yllında, küresel doğal gaz üretim artışı da büyük ölçüde ABD (\%5 artış) kaynaklı olmuştur. Avrupa ve Avrasya'da gaz üretimi görece artış gösterirken, bu artış, Rusya ve Norveç kaynaklı olmuştur. Uluslararası Enerji Ajansı, 2020 yllına kadar olan dönemde, ABD'nin doğal gaz üretiminde belirleyici olacağını ve ülkede üretimin 847 milyar $\mathrm{m}^{3} \mathrm{e}$ ulaşacağını öngörmektedir. 
Ayrıca Orta Doğu (39 milyar $\mathrm{m}^{3}$ ) ve Latin Amerika (21 milyar $\mathrm{m}^{3}$ ) önemli artışların görüleceği bölgeler olarak değerlendirilmektedir (TP, 2016: 6, 13, 16). 2016 yilında dünyanın en büyük 25 petrol ve gaz şirketi içinde de 6 Amerikan, 5 Rus, 3 Çinli ve 3 Hint firması öne çıkmakta; Fransa, Hollanda, Birleşik Krallık, İtalya'nın da petrol şirketleri yer almaktadır. ${ }^{4}$

$A B$, dünyanın en büyük enerji ithalatçısı ve ABD'den sonra ikinci büyük enerji tüketicisidir (Bayraç ve Çildir, 2017: 204). Fosil yakıtlar Avrupa'da baskın enerji kaynağı olmayı sürdürmektedir. AB'de tüketilen enerjinin halen en büyük kısmını (2015 y1lı brüt anakara tüketimi bakımından \%72,6) enerji karmasındaki payının hızlı düşmesine rağmen fosil yakıtlar oluşturmaktadır (Avrupa Çevre Ajansı, 2017).

2014 yilında en büyük petrol ve doğal gaz üreticisi olan ABD'de iklim şüpheciliği diğer OECD ülkelerine göre hâlâ güçlüdür. ABD'nin Kyoto Protokolü'nden çıkma gerekçelerinden biri karbondioksit emisyonu azaltımının ülke ekonomisine vereceği büyük zarardır. ABD örneğinde, iklim değişikliği ekonomik endişelerle reddedilmekte ve gelişmekte olan ülkelerdeki rakipleri karşısında “adil olmayan” yük paylaşımı anlamına gelmektedir (Vezirgiannidou, 2013: 596).

ABD’de iklim değişikliğine yönelik şüphelerin yanı sıra geleneksel olarak enerji güvenliği çerçevesinden bakıldığında da iklim değişikliği sorunu arka planda kalabilmektedir. Enerji güvensizliği büyük ölçüde istikrarsız bölgelerden ithal edilen petrole bağımlılıktan kaynaklanmaktadır ve arzın güvenliği ve fiyat temel endişelerdir. Daha fazla enerji bağımsızlı̆̆1 ihtiyac1 politika alanında sıklıkla vurgulanmaktadır, ancak bu çeşitli şekillerde başarılabilir: ithal kaynaklarının çeşitlendirilmesi, karma yakıtların çeşitlendirilmesi, fosil yakıtların yerli üretiminin artırılması gibi. Temiz enerji karma yakıtların çeşitlendirilmesinde bir rol oynayabilir ve iklim değişikliğine çözümün büyük bir parçasını oluşturabilir. Ancak temiz enerji enerji güvenliğinin sağlanmasında tek seçenek değildir. Bu durumda enerji güvenliği ve iklim değişikliği hedefleri uyumlu olmak zorunda değildir ve enerji güvenliği için getirilen çözümler iklim için zararlı olabilmektedir (Vezirgiannidou, 2013: 598).

İklim politikalarını destekleme yönünde iyimserlik yaratan Obama yönetimi de enerji güvenliği konusunda yenilenebilir ya da temiz enerjiyi

\footnotetext{
${ }^{4}$ ExxonMobil (ABD), PetroChina (Çin), Chevron (ABD), Total (Fransa), Sinopec (Çin), Royal Dutch Shell (Hollanda), Gazprom (Rusya), Rosneft (Rusya), Reliance Industries (Hindistan), LukOil (Rusya), CNOOC (Çin), Phillips 66 (ABD), Schlumberger (ABD), Valero Energy (ABD), Oil \& Natural Gas (Hindistan), Marathon Petroleum (ABD), Surgutneftegas (Rusya), SK Holdings (Güney Kore), Gas Natural Fenosa (İspanya), PTT PCL (Tayland), Transneft (Rusya), BP (Birleşik Krallık), Indian Oil (Hindistan), Eni (İtalya), Petrobras (Brezilya). (https://www.forbes.com/sites/rrapier/2016/03/30/the-worlds-largest-publicoil-and-gas-companies/\#658169873173, 2016).
} 
daha fazla desteklemekten çok, geleneksel yaklaşımı izlemiştir. Başkan Obama'nın çevresel gündemi desteklemesine karşın, petrol kuyusu açma ve petrol üretimi daha geniş destek bulmuştur. Petrol üretimi George W. Bush yönetimi sırasında 2001'de 5.8 $\mathrm{MBPD}^{5}$ 'den 2008'de 4.9 MBPD'ye düşmekle birlikte, sonraki iki yılda 5.5 MBPD'ye yükselmiştir. Ayrıca yeni petrol kuleleri inşa edilmiş ve toplam petrol kulesi sayıs1 2009'dan 2010'a ikiye katlanmış ve 1990'ların sonlarına göre 10 kat artış göstermiştir. Kongre'nin 2011 yasası ile Atlantik kıyısında yeni petrol kuyusu açma yolu açılmıştır ve bu adım söz konusu alanda en azından 2018'e kadar denizde petrol kuyularını yasaklayan önceki politikadan önemli bir değişimi işaret etmektedir (Vezirgiannidou, 2013: 598). Günümüzde de dönemsel olarak farklılıklar göstermekle birlikte, ABD'deki aktif sondaj kule sayısı, dünya ortalamasının \%36'sı ile \%60'ı arasında değişmektedir (TP, 2016: 22). 2015 yllında, arama ve üretim sektöründe gerçekleşen toplam harcamanın 330 milyar dolar düzeyinde olduğu dikkati çekmektedir (TP, 2016: 23).

ABD'de kaya gazı rezervlerinin keşfi ve çıkarılması da doğal gaz üretimini desteklemektedir. Büyük kaya gazı rezervleri enerji güvenliğini sağlamakta, enerji fiyatlarını düşürmekte ve ABD'de imalat sürecini tekrar teşvik etmektedir. Ancak, kaya gazı kömür ve petrole göre daha az sera gazı emisyonu üretmesine karşın, kaya gazının çıkarılması için büyük ölçüde enerjiye ihtiyaç vardır; bu da bir fosil yakıttır ve yenilenebilir enerji kaynakları ile doğrudan rekabet etmektedir. ABD'nin rezervlerinin ölçeği dikkate alındığında, ABD'nin önümüzdeki yıllarda yenilenebilir enerji kaynaklarına göre kaya gazına öncelik vereceği düşünülmektedir (Vezirgiannidou, 2013: 599).

ABD'de fosil yakıtlar aynı zamanda ulaşımda alternatif enerji kaynakları ile rekabet etmektedir. Kömürden elde edilen sıvı yakıt teknolojisi kömürüreticisi eyalet temsilcileri tarafindan desteklenmektedir, ancak bu sera gazı emisyonlarını düşürmeyecektir ve karbon tutma ve depolama olmazsa onları artıracaktır. Ayrıca enerji güvenliğinin sağlanması endişesi en büyük kömür rezervelerine sahip olan ABD'yi yerli kömür üretimini genişletmeye teşvik edebilecektir (Vezirgiannidou, 2013: 599).

EPA'nın 2014'de yayınladığ1 Temiz Enerji Planı'nda sera gazları emisyonlarını azaltma yolları şu şekilde ifade edilmiştir: (i) fosil yakıt enerji tesislerinin etkinliğini artırmak, (ii) doğal gaz kombine tesislerin kapasitesini artırmak ve daha yoğun karbon (kömür) tesislerinin doğal gaz ile çalışanlarla ikame edilmesi, (iii) nükleer enerji tesisleri gibi sıfir-emisyon kaynaklarını sürdürme ve yenilenebilir enerjiden elde edilen elektrik oranını artırma, (iv) elektrik tasarrufu ve etkinliği artırma önlemleri geliştirme (Engel, 2015: 458).

${ }^{5}$ MBPD (million barrels per day): günde milyon varil 
Görüldüğü gibi, fosil yakıtlardan vazgeçme değil, etkinliğini artırma, kömür tesislerinin doğal gaz ile ikame edilmesi gibi öneriler önceliklidir.

ABD'de Başkan Obama sonrası göreve gelen Başkan Trump ile enerji ve iklim politikalarında değişiklikler de ortaya çıkmıştır. Trump 1 Haziran 2017'de Paris İklim Anlaşması'ndan ülkesini çekme kararını açıklamış, Anlaşmanın mevcut şartlarının ABD'nin ekonomik çıarlarına uymadığını savunarak bu sürecin 2020 yılında tamamlanacağını belirtmiştir. Ayrıca yine bu dönemde çıarılan kararnameler, atamalar vb. ile de süreci tersine çevirecek politakaları hayata geçirmiştir.

Başkan Trump, 28 Mart 2017 tarihinde yayınlanan "Enerji Bağımsızlığının ve Ekonomik Büyümenin Teşvik Edilmesi” başııklı bir kararname ile Obama yönetiminin ikinci döneminde hayata geçirilen tüm iklim ve enerji politikalarını yürürlükten kaldırmayı amaçlamaktadır. Bu çerçevede kararnamenin etkileri a) Federal kuruluşlar tarafindan fosil yakıt endüstrisinin deregülasyonu (kuralsılaştırılması); b) Federal arazilerde yeni kömür alanları açılmasına dair moratoryumun kaldırılması; c) Kömür santralleri için kirlilik standartlarının gevşetilmesi; d) Petrol ve gaz alanlarından kaynaklanan metan kirliliği standartlarının gevşetilmesi ve e) Fosil yakıtların sosyal maliyetleri için sera gazlarının etkilerini göz ardı eden eski hesaplama yöntemlerinin kullanılması. Kararnamede iklim değisşikliğiyle mücadeleyi amaçlayan bütün politikalar ulusal çıkarlara, piyasa ekonomisine ve yerli enerji kaynaklarının kullanılmasına engel olan gereksiz yükler olarak sunulmaktadır. Ayrıca Trump'in Çevre Koruma Ajansı (EPA) ve Enerji Bakanlığı gibi kurumların kilit mevkilerinde yaptı̆̆ tartışmalı atamalar, iklim bilimi alanındaki araştırma kuruluşlarının kamudan aldığı fonları kesmesi ve yayınlanan ilk kararnamelerden birinin Keystone XL ve Dakota Access Boru Hattı projelerini canlandırmayı amaçlaması gibi sorunlar da görülmektedir (Ağaçayak vd., 2017: 3).

Benzer şekilde eyalet düzeyinde "yeşil ekonomi”ye yönelik çabalara karşın, hükümet girişimleri bile sıkı bir yeşil gündem geliştirememişlerdir. Örneğin, Recovery and Reinvestment Act yeşil enerji için 16.8 milyar dolar sunarken, emisyonları artıracak olan yol ve köprü inşaatları için 27.5 milyar dolar sağlamıştır. Bunlar "yeşil ekonomi”nin ne anlama geldiği ve nasıl başarılacağı konusunda da sorular yaratmaktadır (Vezirgiannidou, 2013: 604).

Son 10 y1llık dönemde küresel petrol talebi artışının büyük ölçüde Çin kaynaklı olduğu dikkat alındığında (TP, 2016: 13) Çin’in fosil yakıtlara olan bağımlılı̆̆ anlaşılmaktadır. 2010'da Çin'in petrol talebi tüm dünya genelindeki petrol talebinde yaşanan artışın yaklaşık \%40'ı civarındadır. Çin petrol konusunda yayılmacı bir politika gütmekte, $A B D$ ve Britanya'nın adımlarını takip etmektedir. Ülke esas olarak farklı ülkelerde petrol sahaları satın almakta, ülke içinde geçerli şartları belirlemektedir (Giddens, 2013: 71). 
Ayrıca kömür bazlı enerji ve güç sistemleri Çin ekonomisinin hızlı gelişimini desteklemektedir. Dünya kömür üretimi bir yll öncesine kıyasla 2010'da yüzde 2 artmıştır. OECD ülkelerinde kömürün kullanım oranı düşmüş, kömür yakıtlı termik santrallerin inşaatı yavaşlamıştır. Ancak endüstriyel ülkelerde kömür tüketimindeki düşüş özellikle Çin gibi ülkelerdeki artışla dengelenmektedir. Çin Avrupa, ABD ve Japonya'nın toplamından daha fazla kömür tüketmektedir. Çin'de elektrik için kullanılan kömür arzı \%80 iken, ABD'de bu oran \%45'ti (Giddens, 2013: 200). Birincil enerji üretiminde kömürün pay1 1970 yllinda \%82, 2006'da \%76 ve 2012'de \%70 seviyelerinde olmuştur. 2020 ve 2030 ylllarında da enerji tüketiminin en azından \%63’ünü kömürün oluşturacağ1 tahmin edilmektedir (Liu vd, 2015: 256).

Çin'de sanayileşme ve kentleşmenin artışı enerji talebinin hızla artmasına neden olmaktadır. Çin'de 1992'den itibaren yaklaşık 200 milyon kişi kırsal alandan kent çeperine göç etmiştir ve günümüzde kentlere göç eden 15 milyonluk göç akımının önümüzdeki yirmi yılda da devam edeceği beklenmektedir. $\mathrm{Bu}$ açıdan, son tahminlere göre, Çin kentlerinde 2028'e kadar yaklaşık 1 milyar kişi yaşacaktır ve 221 kentin her birinin nüfusu 1 milyondan fazla olacaktır. Sonuç olarak ticari alan da artma gösterecektir. Ayrıca kentsel altyapı ile ilgili çimento, çelik, petro-kimyasallar ve alüminyum gibi temel sektörler en önemli sera gazı emisyon kaynaklarıdır. Bu durum dikkate alındığında, 12. Planın enerji yoğunluğunu \%16 azaltma hedefi hem yeni binaların yapımında hem de mevcut olanlarda önemli değişiklikler yapılmasını gerektirecektir. Enerji, kimya ve ulaşım endüstrileri devletin sahibi olduğu şirketlerin kontrolü altındadır. Bu tekel durumu özel Çin işletmelerinin temiz teknoloji alanlarına erişmesini zorlaştırmaktadır. Çin'de karbon yoğunluğundaki \%17 oranında bir azaltım da dünyanın en büyük sera gazı emisyonu olan ülke olduğu dikkate alındığında, zor bir hedef olarak görünmektedir (Heras, 2014: 25-26). Son yirmi yllda battl ülkelerden imalat süreci de Çin'e doğru kaymıştır. Bu kayma batıdan Çin’e bir tür "salınım transferi" anlamina da gelmektedir (Giddens, 2013: 136).

Çin'in enerji konusundaki olumlu adımlarına karşın, otoriter yapısının politikaları hızlı ve etkin bir şekilde uygulamayı zorlaştırdığı ifade edilmektedir. Çin sistemini çoğunlukla "parçalı otoriterlik" olarak adlandıranların da dikkat çektiği sorunlar politikalar ve yasal düzenlemelerin hem bürokratik seçkinler arasında uzun pazarlıklar nedeniyle zayıflatılması, hem de sistemde aşağıya doğru indikçe sık sık yok sayılmalarıdır (Geall and Hilton, 2014: 180). Çin'de ulusal hükümet tarafından yapılan girişimlerde, yerel yöneticiler ya da işletmeler arasında da çatışmalar çıkabilmektedir. Ayrıca lider yöneticilerde milli geliri artırmak için girişimlerde bulunma serbestliği ve esnekliği vardır. Bu nedenle temel hedef hâlâ ekonomik büyüme projeksiyonlarıdır. 12. Plan ve 13. Plan ulusal enerji yoğunluğu hedeflerinde bazı değişiklikleri içermesine karşın, bunların hayata geçmesi 
Çin'in politik kapasitesinde önemli değişiklikler olmasına bağlıdır (Heras, 2014: 27).

Fosil yakıtların yanması sonucu oluşan karbon emisyonlanı üzerinden karbon vergisi almak iklim değişikliği ile mücadele için önem taşıyan bir uygulamadır (Giddens, 2013: 220 vd.). Ancak ülkeler, uygulanacak vergi miktarlarını ulaşmak istedikleri hedefler doğrultusunda belirlemektedir. Vergiler, emisyon indirimini, fiyat aracılığıyla dolaylı olarak başarabilir. Fakat temel sorun, iklim değişikliğinin tehlikeli boyutlara ulaşması durumunda, ne kadar verginin üreticileri caydırıp, başka enerji kaynaklarını aramaya çalışacağının bilinememesidir. Doğru vergi düzeyini bulmak için farklı vergi oranlarının denenmesi gerekir; fakat yapılacak denemelerle ideal oranı bulmak zordur (Çiçek ve Çiçek, 2012: 112).

Hotunluoğlu ve Tekeli (2007), 18 Avrupa ülkesini' ${ }^{6}$ kapsayan çalışmalarının sonucunda, karbon vergisi uygulayan ülkelerde toplanan çevresel vergilerin karbondioksit emisyonu üzerinde anlamlı bir etkiye sahip olmadığını tespit etmişlerdir. Bunun üç temel nedeni olduğu ileri sürülebilir. Birinci olarak, karbon vergisi ve diğer çevresel vergiler Avrupa Komisyonu tarafından da belirtildiği üzere, homojen bir şekilde tüm karbondioksit emisyonunu kapsamamaktadır. İkinci ve en önemli neden karbon vergisini uygulayan ülkelerdeki bazı sektör ve kesimlere önemli muafiyetler tanınmasıdır. Bu muafiyetler enerji-yoğun, yani enerjiye bağımlı olarak fosil yakıtları önemli miktarda kullanan sektörlere ve uluslararası rekabete duyarlı kesimlere tanınmıştır. Çünkü karbon vergisinin maliyetlerde artış yaratmasıyla enerji yoğun sektörlerin maliyetinin önemli ölçüde artacağ1 ve yine bu vergi nedeniyle artan maliyetlerin uluslararası rekabet kaybina yol açacağ ileri sürülmüş ve hükümet üzerinde önemli etkiye sahip olan sanayi lobileri tarafından desteklenmiştir. Enerji-yoğun sektörler ve rekabete duyarlı kesimler tarafindan hükümet üzerinde yapılan baskıların siyasi anlamda sonuç vermesiyle, bu kesimler karbon vergisinin kendi üzerlerindeki etkisini azaltmışlardır. Dolayısıyla karbondioksit emisyonunun en büyük kaynağı olan bu sektörlerde karbon vergisi amacına uygun olarak işletilemediği için, emisyon azaltım amacını gerçekleştirememektedir. Bu bağlamda demokratik ülkelerde bile hükümetlerin toplumun ortak çıkarlarından çok, bask1 ve çıkar gruplarının çıkarları doğrultusunda kararlar aldıkları gözlenmekte ve bilinmektedir. Üçüncü olarak alınan karbon vergisinin daha çok kamu geliri sağlama aracı olarak kullanılmasıdır. Çünkü karbondioksit emisyonunun hacminin büyüklügü ve fosil yakıtların üretimin hemen her alanında kullanılması neticesinde önemli bir kamu geliri potansiyeli yaratılmaktadır (Hotunluoğlu ve Tekeli, 2007: 121-122). Karbon vergilerinden elde edilen

\footnotetext{
${ }^{6}$ Bu ülkeler Avusturya, Belçika, Danimarka, Estonya, Finlandiya, Yunanistan, İrlanda, İtalya, Lüksemburg, Hollanda, Norveç, Polonya, İspanya, İsveç, İngiltere, Almanya, Çek Cumhuriyeti ve Fransa'dır (Hotunluoğlu ve Tekeli, 2007: 117).
} 
gelirler karbon azaltım programları (iklim değişikliği programları) için veya çevreci amaçlar doğrultusunda vergi indirimleri, enerji etkinliğini artırıc1 önlemleri sübvanse etme amacıyla kullanılabildiği gibi, bütçe açıklarının giderilmesi, işgücü vergilerini azaltmak, gelir vergilerini azaltmak, yatırımlar ve teknolojik gelişmeleri teşvik, gelecekteki devlet borçlarını azaltmak amacıyla devlet borçlarının ödenmesi gibi iklim değişikliği dışındaki amaçlar için de kullanılabilmektedir. Tablo 4'de karbon vergilerinin çoğu ülkede iklim ve enerji dışındaki amaçlar için kullanıldığı görülmektedir. Karbon vergilerinin belirli bir harcama amacı olmadan toplandığ1 ülkelerde bile bu kez vergiden muafiyetler biçiminde politik sınırlılıklar da olabilmektedir (Hahn, 2009: 178). Çevresel amaca yönelik olarak sunulan ve daha sonra amacından uzaklaşan politikalarla küresel çaplı karbondioksit emisyonundaki artış probleminin çözüme kavuşması zor görünmektedir (Hotunluoğlu ve Tekeli, 2007: 121-122) ${ }^{7}$.

\section{Tablo 4: Karbon vergisi gelirlerinin kullanımı}

\begin{tabular}{|l|l|}
\hline Ülke & Karbon vergisi gelirinin kullanımı \\
\hline Finlandiya, 1990 & $\begin{array}{l}\text { Hükümet bütçesini artırmak (kısmen işgücü } \\
\text { vergilerini azaltmak) }\end{array}$ \\
\hline Hollanda, 1990 & $\begin{array}{l}\text { Hükümet bütçesini artırmak (çevresel koruma } \\
\text { harcamaları) }\end{array}$ \\
\hline Norveç, 1991 & $\begin{array}{l}\text { Hükümet bütçesini artırmak (kısmen gelir } \\
\text { vergilerini azaltmak, enerji tasarrufu ve yenilenebilir } \\
\text { enerji için yatırımları artırmak) }\end{array}$ \\
\hline İsveç, 1991 & $\begin{array}{l}\text { Gelir yaratmak (enerji vergisini ve işgücü vergisini } \\
\text { düşürmek) }\end{array}$ \\
\hline Danimarka, 1992 & $\begin{array}{l}\text { Tüm gelir gruplarında marjinal vergi oranlarını } \\
\text { azaltmak }\end{array}$ \\
\hline Birleşik Krallık, 1992 & Gelir artırmak \\
\hline
\end{tabular}

\footnotetext{
7 Karbon vergilerinin öncüleri olan İskandinav ülkelerinde 1990'ların başlarında belirli bir başarı elde edilmiştir. 2000'li yıllarda karbon vergileri sayesinde Finlandiya'da karbon emisyonu, olması gereken seviyenin \% 2-3; İsveç, Norveç ve İzlanda'da \%3-4 daha düşük oranlarda gerçekleşmiştir. Ancak bu ülkelerde mutlak salınım seviyesi doksanlar boyunca artmıştır. Sadece Danimarka'da karbondioksit salınımına ait mutlak hacim düşmüştür. Bunun nedeni, Danimarka'nın vergi gelirlerini çevreyle ilgili amaçlara sevk etmesidir. Burada vergiler enerjide tasarruf uygulamalarını desteklemek için kullanılmıştır (Giddens, 2013: 223-224; Çiçek ve Çiçek, 2012: 100).
} 
Düşük Karbon Ekonomisine Geçme(me): İklim Değişikliği ve Ener...

\begin{tabular}{|c|c|}
\hline Kanada (Quebec), 2007 & $\begin{array}{l}\text { Karbon emisyonlarını azaltmak ve kamu } \\
\text { taşımacılığını geliştirmek için Provincial Green } \\
\text { Fund }\end{array}$ \\
\hline $\begin{array}{l}\text { ABD (Boulder, CO), 2007- } \\
2012\end{array}$ & $\begin{array}{l}\text { Enerji kullanımını azaltmak amacıyla iklim eylem } \\
\text { planı için Boulder Fonu }\end{array}$ \\
\hline $\begin{array}{l}\text { ABD (America's Energy } \\
\text { Security Trust Fund Act), } \\
2007\end{array}$ & $\begin{array}{l}\text { Ücretlerden alınan vergiyi düşürmek (\%2'si } \\
\text { AR\&GE, \%1 etkilenen endüstriler için) }\end{array}$ \\
\hline $\begin{array}{l}\text { ABD (Save Our Climate Act), } \\
2007\end{array}$ & $\begin{array}{l}\text { Vergileri azaltmak, alternatif yakıtların araştırma ve } \\
\text { geliştirilmesi için yapılan harcamaları artırmak ya da } \\
\text { hükümet bütçesini artırmak }\end{array}$ \\
\hline $\begin{array}{ll}\text { Kanada } & \text { (Britanya } \\
\text { Kolombiyas1), } 2008\end{array}$ & Gelir artırmak \\
\hline
\end{tabular}

Kaynak: (Hahn, 2009: 183-184).

Karbon vergilerinin yanında sübvansiyonlar biçimindeki ekonomik araçlar da kullanılabilmektedir. Öncelikle fosil yakıtlara uygulanan sübvansiyonlar daha yüksek orandadır ve devam etmektedir. Örneğin, 2014'de fosil yakıtlardan kaynaklanan küresel karbondioksit emisyonlarının \%13'ü (4.2 Gt), ortalama olarak karbondioksit tonu başına yaklaşık 115 dolar zımni sübvansiyon - tüketim sübvansiyonu - elde etmiştir (IEA, 2015: 23). Yenilenebilir Enerji Global Durum Rapori'na göre, kömür, petrol ve doğalgaza ayrılan yıllık direkt sübvansiyonların tutarı 550 milyar doları aşmaktadır. Uluslararası Para Fonu tarafindan yayınlanan güncel bir analizde söz konusu direkt sübvansiyonlara ek olarak fosil enerjinin sağlık ve iklime verdiği zarar ve dolaylı sübvansiyonlar eklendiğinde y1llık 5 trilyon dolarlık bir miktara ulaşılmaktadır (Deutsche Welle, 2015).

ABD'de de fosil yakıt endüstrisine sağlanan vergi indirimleri ve teşvikler biçimindeki sübvansiyonların düzeyi hâlâ yüksektir. 2002-2008 döneminde, fosil yakıt endüstrileri 72.5 milyar dolar sübvansiyon elde etmiştir; aynı dönemin yenilenebilir enerji sübvansiyonları ise 29 milyar dolardir. Sübvansiyonların azaltılması yönündeki destek, ABD'de büyük bütçe açı̆̆ını ortadan kaldırma gereği ile de birleşmiştir. Ancak hâlâ bu konuda bir uzlaşı yoktur ve bunun nedeni fosil yakıt endüstrisinin karşı çıkışıdır. Kongre'deki Cumhuriyetçiler bütçe açığının azaltılmasını desteklemelerine karşın, sübvansiyonların azaltılmasına karşı çıkmışlardır. Bu yüzden Obama yönetiminde temiz enerjinin desteklenmesi ya da fosil yakit sübvansiyonlarının azaltılması şeklinde "kirli" enerjinin sınırlandırılmasına yönelik beklenen atılım gerçekleşmemiştir (Vezirgiannidou, 2013: 598-599). 
AB'de de yenilenebilir enerji kaynaklarının çok sayıdaki avantajlarına rağmen, halen toplam enerji üretimi içindeki payının $\% 16,7$ gibi düşük olmasının başlıca nedenleri de fosil yakıtlara sağlanan sübvansiyonların sürdürülmesi, kirliliğin toplam maliyetinin fosil yakıtların maliyetine dahil edilmemesi (negatif dışsallıkların içselleştirilememesi) ve yeni yenilenebilir enerji yatırımlarının başlangıç maliyetlerinin oldukça yüksek olmasıdır (Bayraç ve Çildir, 2017: 211). Yenilenebilir enerjinin elektrik üretimindeki payı artmakla birlikte, ulaşımda kullanılan enerjinin sadece \%6.7'sine katkıda bulunmuştur. Kara taşımacilığına olan talebin artması ile 2014 ila 2015 yılları arasında bu sektörden sera gazı emisyonlarında bir miktar artış olmuştur. Hava taşımacilığından yolcu-kilometre başına sera gazı emisyonlanı azalıyor olsa da, halen kara taşımacilığına kıyasla kayda değer düzeyde daha yüksektir (Avrupa Çevre Ajansi, 2017). Ayrica 2016 ve 2017 yllları arasinda genel olarak çelik üretiminden gelen endüstriyel emisyonların artması nedeniyle de genel karbon emisyonlarında artı̧ gözlenmiştir (TENVA, 2018).

\section{2 İklim Politikaları Aracılığıyla Ekonomik Kazanım}

Fosil yakıtları düşündügümüzde gözlenen iklim politikalarına karşı koyuş, iklim politikaları aracıllğıyla ekonomik kazanımların elde edilmesi gündeme geldiğinde düşük karbon ekonomisine geçişi desteklemeye dönüşmektedir.

Newell ve Paterson, küresel ekonominin fosil yakttlara dayanan karbon ekonomisinden uzaklaşma ve kapitalizmin büyüme zorunlulukları ile karbonsuzlaşma projesinin bağlantılı olduğu "iklim kapitalizmi" "ne geçişe işaret etmektedir (Newell, 2012: 136; Newell ve Paterson, 2010).

Bir yandan iklim değişikliğine cevap vermek, küresel ekonominin ve günlük hayatın nasıl düzenlendiği konusunda köklü değişiklikler gerektirmektedir. Giderek yaygin olarak kullanilan "ekonominin karbonsuzlaşması" terimi ekonomiyi işler kılmak için kullandığımız enerjiden karbonu atma sürecini ifade etmektedir. Ancak bu terimin ekonominin nasıl organize edildiğine dair imalan görmezden gelinmekte ya da daha ziyade basit bir teknik soru olarak görülmektedir. Bugün inanmak zor görünebilir, ancak bir zamanlar iş dünyası iklim değişikliği diye bir şey olduğunu inkâr etmiştir. İklim değişikliğinin bilimsel temeline karşı çıkmış ya da BM iklim müzakerelerinde saldırgan lobiciliği sıklıkla kullanmıştır. Bununla birlikte, 1990'ların ortalarından itibaren, büyüleyici bir dönüşüm gerçekleşmiştir. Bir avuç şirket sert eylem biçimlerine direnmeye bir şekilde devam etse de, birçoğu sera gazı düzenlemelerinin devam etmekte olduğunu ve kendilerini bu yeni iş ortamında rekabet etmek ve hayatta kalmak için hazırlamanın daha iyi olacağını hissetmeye başlamıştır. Bu sadece bir risk yönetimi sorunu olmanın ötesinde, karbon-sınırlı bir ekonomide pek çok iyi iş firsatının

8 İklim Kapitalizmi hakkında ayrıntılı bilgi için bkz. Newell, P., Paterson, M. (2010) Climate Capitalism, Cambridge University Press, Cambridge. 
olduğunun farkına varılmasıydı. İklim değişikliği konusunda mücadelenin bir “iş yönü" vardı... (Newell ve Paterson, 2010).

İklim değişikliği sorununun çözümü için ağırlık kazanan teknolojik değişiklikler yeni birikim stratejileri yaratmıştır. Paterson'a (2001) göre, bu birikim stratejisi yenilenebilir enerji kaynakları, enerji etkinliği teknolojileri, düşük karbon üreten ya da karbon-üretmeyen otomobil ve diğer ulaşım teknolojileri üzerinde yükselmektedir. Bu şekilde internet teknolojileri ve biyoteknoloji yanında üçüncü bir teknoloji alanı ortaya çıkmıştır.

Düşük karbon ekonomisine doğru gerçek ve yapisal bir dönüşümün geciktirilmesi için de çevresel, ekonomik ve sosyal maliyetlerin göz ardı edildiği teknik, finansal ve kurumsal çözüm önerileri ileri sürülmektedir; (i) Teknik öneriler: Tarımsal ürünlere dayalı yakıtlar, nükleer enerji, karbon yakalama ve depolama teknolojileri, mono-kültür tarımı, genetiği değiştirilmiş organizmalar vb.; (ii) Finansal öneriler: Karbon denkleştirme (offset), karbon ticareti, teknoloji, ürün ve hizmet patentleri, bazı sinır gümrük vergileri vb.; (iii) Kurumsal öneriler: İklim finansmanının neoliberal ekonomi kurumları aracıllğı ile kanalize edilmesi, temiz teknolojiler adı altında fosil yakıt temelli ve/veya çevresel ve sosyal etkisi fazla olan teknolojilere sağlanan fon mekanizmalar1 vb. (Turhan vd., 2017: 48-49).

$\mathrm{Bu}$ durumda iklim değişikliği ile mücadelede yer alma nedeni ağırlıklı olarak ekonomik kalkınma ve çevresel korumanın "kazan-kazan" söylemine dayanmaktadır. Bu şekilde yeşil ekonomi, yeşil büyüme söylemleri artarak devam etmektedir. İklim değişikliğinde sera gazı emisyonlarının azaltılması konusunda bir uzlaşı sağlamak zor olduğundan, politik olarak daha çok ortak-faydalara (ekonomik, kamu sağlığı) dayanılmaktadır. Ancak bu durumda sonuçlar en ılımlı olanlardır ve yükselen emisyonlarda bir azalmaya neden olmaz. Bu nedenle iklim ve ekonomik hedefleri bir araya getiren resim karmaşıktır. Bir tarafta bu yaklaşım iklim önlemlerini daha kabul edilebilir kılar, ancak diğer yanda aktörleri asgari önlemlerin ilerisine gitmeye zorlamaz. "Kazan-kazan" retoriği devletler, şirketler ve NGO'ların gündemlerini etkilemektedir (Vezirgiannidou, 2013: 602-603).

Öncelikle iklim değişikliği, sera gazlarının azaltılması için yenilenebilir enerji kaynaklarının kullanımının artması yönünde teşvik edici olmaktadır. 2014'ün sonu itibariyle, küresel elektrik üretiminde kaynakların dağılımı fosil yakıtlar ve nükleer $\% 77.2$, yenilenebilir enerji $\% 22.8$ 'dir (hidroenerji $\% 16.6$, rüzgar $\% 3.1$, biyo-enerji $\% 1.8$, güneş $\mathrm{FV} \% 0.9$, jeotermal, yoğunlaştırılmış güneş enerjisi sistemleri (concentrating solar power-CSP) ve okyanus \%0.4) (REN21, 2015: 18). 2014 y1l itibariyle küresel enerji kapasitesine yapilan ilavenin yaklassık \%58.3'ü yenilenebilir enerjiden oluşmaktadır. Kapasite artışında hidroenerji, rüzgar ve güneş enerjisi en öndedir (REN21, 2015: $6,9)$. 
Avrupa Birliği düşük-karbon teknolojilerinin sağlayıcısı ve kullanıcısı olarak lider olmuştur. ABD de temel bilimsel araştırma ve araştırmadan ürüne dönüşen teknolojik ilerlemede liderdir. Son yllarda Çin teknoloji sunucusu olarak ortaya çıkmıştır ve güneş enerjisi gibi bazı alanlarda Avrupa'dan da ileridedir.

Ylllk yenilenebilir enerji yatırımları 2004'de 45 milyar dolar, 2014'de 270 milyar dolardır. Yenilenebilir enerji ve yakıtlarında (50 MW altı hidroenerji hariç) 2014 yllı itibariyle yıllık yatırımda ilk beş ülke Çin, ABD, Japonya, Birleşik Krallık ve Almanya'dır. 2014'de hidroenerjide Çin, fotovoltaik güneş panelleri kapasitesinde Çin, yoğunlaştırılmış güneş enerjisi sistemleri (CSP) kapasitesinde $\mathrm{ABD}$, rüzgar enerjisi kapasitesinde Çin, solar su isitma kapasitesinde Çin, biyodizel üretiminde $\mathrm{ABD}$, etanol yakıtı üretiminde $\mathrm{ABD}$ ilk siradadır. 2014 sonu itibariyle toplam kapasite ya da üretim olarak yenilenebilir enerji (hidroenerji dahil) ilk beş ülke Çin, ABD, Brezilya, Almanya, Kanada; hidroenerji hariç Çin, ABD, Almanya İspanya/İtalya, Japonya/Hindistan'dır (REN 21, 2015: 9-10). 2017 itibariyle, yenilenebilir enerjide en büyük 10 şirket içinde 4 Çin, 2 Alman, 2 Amerikan, 1 Kanadalı, 1 Hintli şirket yer almaktadır. ${ }^{9}$

AB'de yenilenebilir enerji kaynakları elektrik üretiminde önemli bir katk1 sağlamış; 2017 yllında toplamda tüm elektriğin \%20.9’u rüzgar, güneş enerjisi ve biyokütle, \%10.9'u hidro kaynaklardan elde edilirken, nükleerin pay1 $\% 26.5$, kömürün pay1 \%20.6, doğalgazın ise $\% 19.7$ olarak gerçekleşmiştir (Avrupa Çevre Ajansı, 2017). ${ }^{10}$ AB'nin yenilenebilir enerji kaynaklarının kullanımındaki atılımında enerjide dışa bağımlılığın azaltılması politikası önemli rol oynamaktadır. $A B$ dünyada enerji tüketiminin en fazla olduğu bölgelerden biri olmasına karşın, enerji kaynakları açısından yetersiz olması nedeniyle enerjide dışa bağımlıdır. Tükettiği enerjinin \%54'ünü ithal etmek zorunda olan birliğin ithalat bağımlılı̆̆ her geçen yıl daha da artmaktadır. Bu oranın 2030 yllına kadar \%57,4-\%59,1 düzeyine çıkacağı beklenmektedir. AB

\footnotetext{
${ }^{9}$ Canadian Solar Inc, Güneş enerjisi, Kanada; CropEnergies AG, biyoyakıtlar, Almanya; First Solar Inc, Güneş enerjisi panelleri, ABD; GCL-Poly Energy Holdings Ltd, Yeşil enerji, Hong Kong, Çin; Global Pvq SE, Fotovoltaik güneş panelleri, Almanya; Green Plains Inc, Ethanol, ABD; Guodian Technology \& Environment Group Corp Ltd, Karbon azaltma, sülfürdioksit kontrolü, nitrat uzaklaştırma, su arıtma teknolojileri, Çin; Hanergy Thin Film Power Group Ltd, Güneş panelleri, Hong-Kong, Çin; Inox Wind Ltd, Rüzgar tirbünleri, Hindistan; Jiangsu Akcome Science \& Technology Co Ltd, Fotovoltaik güneş panelleri, Çin (http://www.businessinsider.com/top-25-renewable-energy-companies-thomson-reuters-

2017-11, 2017).

${ }^{10}$ Birlik içinde 2015 yllı itibarıle yenilenebilir enerji kaynaklarının brüt nihai enerji tüketimi içindeki payı açısından, en yüksek oran \%53.9 ile İsveç'te gerçekleşmiştir. Bu ülkeyi sırasıyla, \%39,3 ile Finlandiya, \%37,6 ile Letonya, \%33 ile Avusturya takip etmiştir. Yenilenebilir enerji kaynaklı tüketimin en az gerçekleştiği ülkeler ise, $\% 5$ ile Malta ve Lüksemburg'dur. Bunları \%5,8 ile Hollanda, \%7,9 ile Belçika, \%8,2 ile İngiltere ve \%9,4 ile Güney Kıbrıs izlemektedir (Bayraç ve Çildir, 2017: 206).
} 
genelinde petrole bağımlılık yaklaşık $\% 90$, doğal gaza bağımlılık $\% 66$, katı yakıtlara bağımlılık $\% 42$ ve nükleer enerjiye bağımlılık $\% 40$ düzeylerindedir. AB'nin 2030 yll itibariyle petrolde $\% 93$, doğal gazda ise $\% 84$ oranında dışa bağımlı olacağı tahmin edilmektedir (Bayraç ve Çildir, 2017: 204).

AB için yapılan ampirik analizler yenilebilir kaynaklardan gerçekleştirilen enerji üretiminin ekonomik büyümeyi kısa ve uzun dönemde olumlu olarak etkilemekte olduğunu göstermektedir (Bayraç ve Çildir, 2017: 211). AB'de buna bağlı olarak ülkelerin pek çoğunda yenilebilir enerji kaynakları kullanımının özendirildiği, enerji politikaları içinde alternatif enerji yatırımlarının teşvik edildiği de görülmektedir. ${ }^{11}$

AB ülkelerinden bazılarına bakıldığında (Giddens, 2013: 118-128), Almanya'da yenilenebilir kaynaklardan elde edilen elektriğin oranı 2000'de \%6.3 iken, 2011'de \%14'ün üzerine çıkmıştır. 20.000 rüzgar türbini ile en çok rüzgar enerjisinden yararlanan ülkelerden olduğu gibi, fotovoltaik güneş enerjisi üretiminde de en büyük ülkelerdendir. Tüm Avrupa'daki güneş enerjisi kapasitesinin \%80'i Almanya'dadır. Ancak önemli sorunlar1 da vardır. Enerji üretimi noktasında kömür ağırlı̆ı vardır. Kömüre dayalı santraller ülke elektriğinin yaklaşık yarısını temin etmektedir. Hedef 2050'de yenilenebilir kaynakların ülke enerjisinin $\% 60$ 'ını üretmesidir. Böyle bir hedef köklü bir değişimi gerektirmektedir, çünkü 2010 itibariyle ülkede inşaat halinde ya da planlanan 22 adet kömür ya da linyit santrali vardır. Bu nedenle hükümet daha çok karbon yakalama ve depolamaya ümit bağlamaktadır. Danimarka'da sosyal demokratların hakim olduğu 1997-2003'de her yil ortalama 325 megavatlık rüzgar enerjisi kapasitesi geliştirilmiştir. Sosyal demokratlardan sonra iktidara gelen sağ-merkezci hükümet döneminde bu ortalama 3 megavata çekilmiş, projelendirilmiş üç yeni rüzgar çiftliği iptal edilmiş, 2007'de var olanlar da sökülmüştür. 2011 itibariyle Danimarka enerjisinin yaklaşık \%80'i fosil yakıtlardan elde edilmiştir. İspanya ve Portekiz'de yenilenebilir kaynaklardan elde edilen enerji oran1 on yılda $\% 2$ 'den \%12.5'e çıkmıştır. Ancak İspanya ve Portekiz'de yenilenebilir kaynakların oranı yüksek olmasına karşın, bu ülkelerdeki sera gazı salımlarında önemli bir azalmaya tanıklık edilmemektedir. Çünkü emisyonların toplam düzeyi ekonominin geri kalanına bağlıdır. İspanya'da 2008 toplam emisyonlar1 1990 düzeyinin 43 puan üstündedir; Portekiz'de ise yüzde 30 daha yüksektir. Birleşik Krallık tüm partilerin desteği ile oluşturulmuş, dünyanın en sağlam karbon salınımını azaltma çerçevesine

\footnotetext{
${ }^{11} \mathrm{AB}$ 'de uygulanan başlıca teşvikler; geliri artırmaya yönelik sübvansiyonlar (Tarife Vergisi ve Portföy Standardı vb.) ve maliyeti azaltmaya yönelik vergi teşvikleri şeklinde kullanılmaktadır. Vergi teşvikleri özellikle yenilenebilir enerji teknolojilerinin başlangıç maliyetlerinin düşürülmesinde ve enerji piyasasına girişin hızlandırılmasında oldukça etkili araçlardır. Yenilenebilir enerji üretimine yönelik diğer bazı teşvikler; sabit fiyat garantisi, prim sistemi, zorunlu kota ve yeşil sertifika uygulamaları ve yatırım kredileridir (ayrıntılı bilgi için bkz. Bayraç ve Çildir, 2017: 206-207).
} 
sahip ülkesidir. Ülkenin kömüre daha az bağıml olmas1 sebebiyle, örneğin Almanya'ya göre daha avantajlıdır. Ancak onun da yüzleştiği sorunlar vardır. $27 \mathrm{AB}$ ülkesi içinde yenilenebilir enerji konusunda en gerideki ülkesidir. Yukarıda sayılan $\mathrm{AB}$ ülkeleri karbon salınımını azaltma konusunda en yoğun performansı göstermiş olsalar da, kaydetmiş oldukları ilerleme oldukça sınırlıdır. Almanya ve Danimarka dışında, salımların azaltılması bağlamında diğer ülkelerin birlik içinde en üst sıralarda bulunmalarının nedeni onların iklim değişikliğinden çok enerji güvenliğinden yana olmalarıdır. Germanwatch ve İklim Eylem Ağı ülkelerin uyguladıkları iklim değişikliği politikalarının etkililiği bağlamında ülkeleri sıralamaktadır. Sıralamayı yapanlara göre, dünyadaki hiçbir ülke sıcaklığ $2 \mathrm{C}$ derecenin altında tutma konusunda kayda değer bir adım atabilmiş değildir (Giddens, 2013: 128, 133).

Yenilenebilir enerjinin yanı sıra karbon piyasası gibi önlemler de finans sektörü vb. sektörler için iklim politikasını meşrulaştıran bir işlev yüklenmiş olmaktadır (Paterson, 2012: 89).

Literatürde diğer sera gazları da karbon eş değeri olarak çevrildiğinden, genellikle sera gazlarının tümünü temsil eden karbon piyasası, piyasa kuralları doğrultusunda çalışmak koşulu ile salımları azaltmada önemli bir araç olarak görülmektedir. Ülkelerin emisyon azaltım maliyetlerinin birbirlerinden farkllık göstermesi nedeniyle, karbon piyasasının salımları azaltmak için belirlenen limitten fazla salım yapanları cezalandırırken daha az salanlar1 ödüllendirerek mevcut kaynakların en düşük maliyetle kanalize edilmesini sağlayacağı öngörülmektedir (Çevre ve Orman Bakanlığı, 2008: 19; Çelikkol ve Özkan, 2011: 207).

Dünya Bankası (World Bank, 2015) verilerine göre, 40 ülke ve 20'den fazla şehir, eyalet ve bölgede karbon fiyatlandırması uygulanmaktadır. Karbon fiyatlandırma araçları bu bölgelerdeki emisyonların yaklaşık yarısını kapsamaktadır; bir başka deyişle, küresel emisyonların \%12'sine (7 GtCO2) denk gelmektedir (World Bank, 2015: 20). 2008'de piyasanın toplam işlem hacmi 4.811 MtCO2'dir ve 2005 yllına göre yaklaşık yedi kat artış göstermiştir. Ayrıca 2008 yllında toplam işlem değeri 126.345 milyon dolara yükselerek 2005 ylının yaklaşık oniki katına ulaşmıştır. Bu toplam hacmin yaklaşık \%64'ü ve alım-satım değerinin yaklaşık \%73’ü AB ETS kapsamındaki emisyon izinleri ve türev ürünleri işlemlerinden kaynaklanmaktadır. 2008 ylında Temiz Kalkınma Mekanizması yatırımları sonucu kazanılan CER'lerin ikincil piyasası, karbon piyasasındaki ikinci büyük kesimi oluşturmaktadır. Bu finansal piyasadaki 26.277 milyon doları aşan işlem değeri 2007 yllına göre beş kat yükselmiştir (Çelikkol ve Özkan, 2011: 207-208). Gönüllü karbon piyasası pazar büyüklüğü 2014 yll1 itibariyle, işlem hacmi olarak $87 \mathrm{MtCO} 2 \mathrm{e}$, işlem değeri olarak 395 milyon dolardır (Ekinci ve Gönençgil, 2015: 70). Temiz Kalkınma Mekanizması açısından 
da, Çin dünyadaki en büyük pazardır ve CDM azaltma projelerinin $\% 43.25$ 'ine evsahipliği yapmaktadır. Bu oran Latin Amerika, Afrika ve Orta Doğu'nun potansiyellerinin toplamına denk gelmektedir (Liu vd, 2015: 257).

Paterson'a (2012) göre, karbon piyasalarının dünyada hizla yaygınlaşmasının öncelikle geniş kabul gören üç nedeni vardır: diplomatik pazarlıklar, esneklik elde etmek ve etkinlik sağlamak. Birinci olarak Kyoto'daki diplomatik pazarllklar sonucunda, ABD'nin muhalefeti karşısında diğer devletlerin ABD'nin imzalayabileceği bir anlaşma elde etme isteğiyle karbon ticareti anlaşmanın bir parçası olmuştur. İkinci olarak esneklik talebi emisyon sınırlamalarının yüksek maliyeti nedeniyle birçok devletin, (özellikle $A B D$ ve Norveç), yükümlülüklerini başka ülkelerde emisyon kısıtlamalarına yatırım yaparak karşılama taleplerini içermektedir. Üçüncü olarak etkinlik talebinde, emisyonların en azından toplam maliyetlerini azaltma ve tüm aktörler için de marjinal maliyetleri eşitleme talebi vardır (Paterson, 2012: 83).

Piyasa temelli araçlar olarak karbon piyasalarına yönelik söz konusu talep ve destek devam etmektedir. Günümüzde de karbondioksit emisyonlarına makul bir fiyat belirlemek $2 \mathrm{C}$ derecelik iklim hedefini başarmanın ayrılmaz bir parçası olarak görülmektedir (IEA, 2015: 23).

Giddens'a (2013: 182) göre, karşı çıkan şirketlerin politikalarını değiştirme nedenlerinden bir kısmı karbon piyasaları ile karbon vergilerinin olası varlığına karşı cevap üretmek istemeleri, diğer bir kısmı ise kendi içlerindeki pazar ve müşteri odaklı değişim ihtiyacına cevap vermek istemeleri ile ilgilidir.

Paterson (2012: 83) ek olarak iki ekonomi-politik nedene de işaret etmektedir. Paterson'a göre, karbon piyasalarının popüler olmasının birinci nedeni, bu piyasaların sera gazı emisyonlarının sinırlandırılmasından yarar sağlayan politik bir "kazanan" koalisyonun kurulmasına imkan tanımasıdır. İkinci olarak karbon piyasaları işletmelerin, karbonsuzlaştırma süreçlerine yardım edebilecek şekilde, bu piyasalara dayanan yatırım, kâr ve büyüme döngüsünü görebilmelerini sağlamıştır. Bu iki neden karşılıklı olarak yakından bağlantılıdır, çünkü karbon piyasalarına dahil olan işletmeler karbon piyasaları ile ya da karbon finansmanı ile büyüme olasılıklarını fark etmişlerdir ve karbonsuzlaştırma koalisyonlarına yönelmişlerdir (Paterson, 2012: 83). Örneğin, 1995'de Küresel İklim Koalisyonu (Global Climate Coalition) emisyonların kısıtlanmasına güçlü bir şekilde karşı çıkan bir blok iken, 2000'lerin başından itibaren, bir örgüt olarak zamanla dağılmış ve ilk üyelerinin çoğu sonradan emisyonların kısıtlanmasını destekleyici bir pozisyon almıstır. İkinci olarak iklim değişikliğinde bir sektör olarak finans sektörünün çıkarları önemli ölçüde genişlemiştir. Kurumsal yatırımcıların çlkarları ilk zamanlarda iklim risklerine maruz kalan sigorta şirketlerinin çıarlarından oluşmakta iken, sonraları daha çok sayıda firmanın karbon 
yoğunluklarını potansiyel bir işletme riski olarak düşünmeye başlaması ile genişlemiştir. Karbon Saydamlık Projesi ${ }^{12}$ (Carbon Disclosure Project) bu tür bir bağlantının göstergesidir. Uluslararası Emisyon Ticareti Birliği (International Emissions Trading Association -IETA), Karbon Piyasaları ve Yatırımcilar Birliği (Carbon Markets and Investors Association CMIA) gibi bu tür firmaları temsil eden büyük finans ve lobi grupları vardır. Bu temsilci örgütlerin artık emisyonların azaltılması konusunda büyük hedeflerin devam ettirilmesinde çıarları vardır; daha büyük emisyon kısıtlamaları oldukça, daha fazla ticaret olacaktır ve firmaların karbon fiyatlarındaki dalgalanmalara karşı korunmak için türev piyasaların oluşturulması ve Temiz Kalkınma Mekanizması gibi telafi edici mekanizmalara erişme talepleri artacaktır (Paterson, 2012: 87).

Diğer yandan çevresel NGO'lar da çeşitli karbon piyasası şirketlerini desteklemektedirler. Bu nedenle söz konusu aktörler arasındaki sınırlar da net ve kesin değildir ve devlet, şirket, NGO sınırları arasında geçişkenlikler olabilmektedir. Bu koalisyon basitçe siyaset biliminde pluralist perspektiften, hükümetlerin birçok farklı sosyal ve ekonomik gruptan etkilendiği şeklinde açıklanabilir. Paterson'a göre ise burada dengelerin değişmesine neden olan asıl unsur sadece finans sektörünün karbon piyasalarının var olmasına ilişkin yönlendirici koalisyonudur. Paterson bu dönüşümde küresel ekonomide finans sektörünün büyüyen etkisine işaret etmektedir (Paterson, 2012: 8788).

Karbon piyasalarının desteklenmesi iklim değişikliği ile mücadele açısından önemli bir etki göstermekle birlikte, söz konusu şirket ve üst örgütlerinin taleplerinin süreci kendilerinin lehine şekillendirdiği görülmektedir.

Algan (2011) çalışmasında ulusötesi şirketlerin Avrupa Sanayiciler Birliği ve Avrupa İş Dünyası Konfederasyonu aracilığıla emisyon ticaret sistemi (ETS) ile ilgili $\mathrm{AB}$ politikalarını etkileme gücünü incelemekte ve ETS'nin ulusötesi şirketlere nasıl hizmet ettiğini ortaya koymaktadır. Birçok sanayi ve enerji şirketinin mensup olduğu Avrupa Sanayiciler Birliği (European Round Table of Indusrialists-ERT ${ }^{13}$ ) ve Avrupa İş Dünyası Konfederasyonu

\footnotetext{
12 Karbon Saydamlık Projesi (Carbon Disclosure Project- CDP) işletmelere karbon ayak izlerini ve karbon azaltma programlarını bildirmeleri için baskı uygulamak amacıyla küresel bir grup yatırımcı tarafindan 2003 yılında oluşturulan bir gruptur. CDP, şirketlerden alınan çevre ile ilgili veri ve bilgiler ile iklim değişiklikleri risklerinin şirketler tarafından nasıl yönetildiğine iliş̧kin yıllık analiz ve tematik raporlar hazırlamaktadır. (Çevre ve Orman Bakanlığı, 2016; TİSK vd, 2016: 22).

13 Avrupa Sanayiciler Birliği (ERT), Avrupa'da sanayi ve teknoloji alanında faaliyet gösteren 45 ulusötesi şirketin başkanlarını ve üst düzey yöneticilerini bir araya getiren, 1 trilyon Euro ciroya sahip olan ve 6,6 milyon kişi istihdam eden bir oluşumdur. Avrupa İş Dünyası Konfederasyonu (UNICE) 35 ülkeden 41 Konfederasyonun üye olduğu 20 milyon şirketi temsil etmektedir (Algan, 2011: 93-94).
} 
(Union of Industrial and Employer's Confederations of Europe-UNICE) için $\mathrm{AB}$ iklim değişikliği ve enerji politikaları büyük önem arz etmektedir. Bu önem; AB tarafindan bu politika alanlarında alınacak kararlara ve yaptırımlara şirketlerin uyma zorunluluğunun ötesinde bu politikaların yaratacağ1 mali hacimden kaynaklanmaktadır. ERT ve UNICE'yi oluşturan ulusötesi şirketler için iklim değişikliği önlemleri ve özellikle emisyon ticareti sistemi çok büyük bir pazar anlamına gelmektedir. Daha önce ifade edildiği gibi, AB ETS'nin pazar değeri 2005 yilinda ilk kurulduğunda 10 milyar dolar iken 2007 y1lında 64 milyar dolar olmuştur. 2008 y1lında 4 milyar ton karbondioksitin satıldığı sistemin hacmi 120 milyar dolara ulaşmıştır. 2020 yılında karbondioksit satışının dört kat daha artarak 16 milyar tona ulaşması beklenmektedir. AB ETS'nin bu büyüklükteki pazar olması nedeniyle, programla ilgili yapılacak düzenlemelerde de söz konusu şirket ve üst örgütlerinin etkisi görülebilmektedir (Algan, 2011: 94-95).14

$\mathrm{Bu}$ noktada ekonominin çeşitli tarafları ile endüstri ve çevreci gruplar arasında gerilimler de gözlenebilmektedir. Newel (2012: 136) ve Paterson (2012: 91) iklim kapitalizminin birçok ikilem ve çatışmayı içerdiğine dikkat çekmektedirler. Paterson'a göre, karbon piyasasında kazanan koalisyon içinde birinci gerilim hedeflerin sıkılığı konusundadır. Bir tarafta finans sektörü, yükselen yenilenebilir enerji sektörleri ve çevresel NGO’lar sık1 tedbirleri desteklerler (450 ppm, hatta 350 ya da 400 ppm gibi). Çevresel NGO’lar bunu belirgin çevresel nedenlerle; yükselen endüstriler yenilenebilir enerjiler ve etkin enerji teknolojilerinin daha hızlı yaygınlaşmasından yararlanacakları için desteklemektedirler. Ancak finans sektörü bir tarafta daha çok ticaret yapabilmeleri için karbon fiyatlarının artmasını, diğer yandan artan karbon fiyatlarının yaratacağı risklere karşı korunmak isterler. Emisyon izin ticareti sistemlerinde izinlerin açık artırma ile satulmasını savunurlar. Diğer tarafta karbon piyasalarını destekleyen firmalar çıkarları gereği, karbon vergileri ya da doğrudan düzenleme gibi emir ve kontrol araçları yerine emisyon ticareti gibi piyasa temelli araçlara daha iyi uyum sağlarken, yine de karbonsuzlaşmaya daha yavaş geçiş için görece zayıf hedefleri tercih

\footnotetext{
14 Algan'a (2011: 104) göre, ERT ve UNICE öncelikle sistem ile ilgili verilecek kararlarn sanayinin rekabet gücünü olumsuz yönde etkilemeyecek kararlar olmasin istemektedir. Sistemin yönetilmesi ve sisteme bağh vergilendirme ile ilgili kararlarn sanayi lebine olmasin talep eden ERT ve UNICE, AB'ye bu isteklerini kabul ettirmistir. ERT ve UNICE'nin bir diğer talebi sanayinin desteklenmesidir. AB, 3.uygulama dönemi için AB düzeyinde kurallar belirlenmesini karara bağlamıstır. Böylece ETS tek bir çatıdan yönetilecek ve tüm ülkeler ve sektörler için kurallar aym olacaktır. Bu uygulama ERT ve UNICE sirketlerinin hem rahat faaliyet etmelerini sağlayacak hem de ERT ve UNICE'yi tek tek ülkelerin politikalarm yönlendirmekten kurtaracaktır. ERT ve UNICE'nin talepleri dogrultusunda ETS planlamasımn küresel boyutta yapılması ve Kyoto Protokolünün diğer mekanizmalarmm çalıstımlması ulusötesi sirketlerin emisyon pazarm genisletecektir. AB ETS böylece bem daha etkin işleyecek bem de sistem genişlediği için sirketlerin kazanmlar artacaktır. Aym şekilde sistemin diğer gazlar ve sektörleri kapsayacak sekilde genişlemesi de Avrupa sanayisinin kazanimlarm artıracaktor. ERT ve UNICE'nin $A B$ ETS ile ilgili son talepleri sistemin ölcme, izleme ve değerlendirmesinin yapılabilmesidir. AB'nin 3. uygulama döneminde merkezi kayıt sistemini zorunlu kilması bu talebin cevaplanmasidır.
} 
edeceklerdir. Özellikle geçiş maliyetlerini tüketicilere yansıtamayan ve büyük ölçüde uluslararası rekabetin işlediği izin ticareti sistemlerinde işletmeler aynı zamanda izinlerin bedava dağıtılmasını tercih edeceklerdir. Kurumsal yatırımcıların da karmaşı, belirsiz çıarları olabilir; kısa dönem yatırımlarının başarısı firmaların piyasa performansına bağımlı iken, uzun dönemde karbondioksit yoğun endüstrilerin baskılarına maruz kalmaktan endişe duyabilirler. Hedeflerin sıkıllğı konusundaki gerilimlerin yanı sıra karbon piyasalarının nasıl tasarlanacağ1, karbon azaltma projelerinin özgün katkılarının nasıl değerlendirileceği ${ }^{15}$ farklı karbon piyasalarının birbirleri ile nasıl entegre edileceği gibi konularda da sektörler arasında çatş̧malar olabilmektedir. Bu noktada söz konusu gerilimlerin çözülmesinde, gerilimi çözebilmesine karşın ekonomik büyümeyi sınırlandırmak yerine teşvik eden araçlar tercih edilmektedir (Paterson, 2012: 92-93).

AB ETS'nin emisyonlar üzerinde belli bir etkisi olmuştur. Örneğin, 2005 'teki emisyonlar programın yürürlüğe girmesinden öncesine kıyasla $\% 7$ daha azdır. Ancak ETS sistemi parasal olarak çok büyük olmasına karşın, program amaçları bakımından epey etkisiz kalmıştır. Oluşturulduğu dönemde karbon fiyatı ton başına 31 avroya ulaşmıştır. Sonrasında bu değer toplamda sent başina 0.001'e kadar düşmüştür. Yaşanan mali durgunluklarla birlikte, değeri daha da azalmıştır. Ayrıca bazı enerji üreten şirketler ücretsiz dağıtılan karbon kredilerinin bedelini tüketicilere yükleyerek muazzam kârlar elde etmişlerdir (Giddens, 2013: 287).

Başlangiçta Amerikan endüstrisi de her tip düzenlemeye karşı iken, artık uzlaşı içinde değillerdir; önemli bir kısmı sera gazı emisyonlarının azaltılmasını savunmaktadır. 2009 yılında ABD emisyon kısıtlamaları ile ilgili bir görüş yayımlamış olan Business Council for Sustainable Energy ve World Business Council for Sustainable Development gibi gruplar ve Climate Action Partnership (CAP) gibi etkili NGO/endüstri koalisyonu emisyon izin ticareti mekanizması ile desteklenen "kazan-kazan" söyleminin savunucularıdırlar. Endüstri gönüllü emisyon ticaret programı olan Chicago İklim Borsası (CCX) gibi gönüllü girişimleri de teşvik etmektedir. Bu girişim 2003'de başlamış, ancak aşırı-tahsis nedeniyle düşük emisyon fiyatları nedeniyle 2010 yllına kadar faaliyet göstermiştir. Bu aktörler ekonomik

\footnotetext{
${ }^{15 S u ̈ r d u ̈ r u ̈ l e b i l i r ~ k a l k ı n m a ~ i l e ~ i l g i l i ~ o l a r a k ~ b i r c ̧ o k ~ C D M ~ p r o j e ~ p a y d a s ̧ ı n ı n ~ e s a s ~ o l a r a k ~}$ sürdürülebilir kalkınmayı teşvik etmekle ilgilenmeden, daha fazla kar elde etmeyi bekledikleri ifade edilmektedir (Heras, 2014: 30). Kyoto'da müzakere edilen faydalara göre, projelerin istihdam geliştirme, yerel ürünlerin kullanımı, teknoloji transferi ve diğer sağlık ve çevre faydaları gibi kalkınma sağlama işlevi vardır. Ancak artan sayıda kanıt, bunun beklendiği ölçekte gerçekleşmediğini göstermektedir. Newell'in ifade ettiğine göre, CDM projelerinin başlangıcından 2007'ye kadar kayıt edilen projelerin \%40'ının özgün katkısı ya yoktur ya da şüphelidir. Hindistan (dünyada CDM projelerinin ikinci en büyük evsahibi ülkesi) gibi ülkelerde hiçbir CDM projesinin gerçekten özgün katkısının olmadığı ifade edilmektedir. Arjantin ve Güney Afrika için de birçok projenin gerçekten özgün katkısının olup olmadığı konusunda büyük şüpheler vardır (Newell, 2012: 137).
} 
ortak-faydaları, hafif düzenleyici yaklassımı vurgulayan, piyasa mekanizmaları, teknolojik inovasyon, kamu-özel ortaklıkları ve gönüllü endüstriyel hedeflere odaklanan ekolojik modernleşme düşüncesinden etkilenmektedirler. Diğer ülkelerdeki yeşil teknolojiye ilk geçen rakipleri ile rekabet etme özel sektörün emisyon azaltma çabalarına katılım isteklerini kısmen açıklamaktadır. Aynı şekilde bu, olası emredici kontrollere hazırlanma ve kendi kamusal imajlarını geliştirme yoludur. Ancak emisyon azaltmak için çoğu eyalet ve belediye girişimleri gibi özel sektör çabaları da en 1 lımlı sonuçları ortaya çıkarmaktadır. Bu isteklilik sera gazı emisyonlarında daha endüstri dostu ve gönüllü/piyasa temelli düzenleme tiplerinin geliştirilmesini sağlama ve yukarıdan-aşağıya daha sıkı düzenleyici yaklaşımları engelleme yolu olarak anlaş1labilir (Vezirgiannidou, 2013: 602-603).

Yenilenebilir enerji yatırımları ve karbon piyasalarının yanı sıra iklim değişikliği ile mücadele için başka yatırım alanları da çıkmaktadır. Birçok şirket "ekolojik serbest pazar ekonomisi"nden söz etmektedir. "Önce kirlet, sonra temizle, kâr et” mantığı da sürdürülmektedir. New Orleans'ın toksik atıklardan temizlenmesi ve yeniden yapılandırılmasında pastadan en büyük payı Exxon-Mobil ve Halliburton gibi ulusötesi devler almıştır. Benzeri şirketler iklim kontrolü politikasını da bu mantıkla hazırlamaktadırlar. Örneğin, sera gazı emisyonlarını sıkıştırıp depolamak ve toprağa gömmek de yeşil teknolojiden sayılmaktadır (Değirmenci, 2007: 27). Karbon tutma ve depolama (carbon capture and storage- CCS), karbondioksiti enerji üretimi veya diğer sanayi tesisleri baca gazından ayırma, taşıma ve uzun dönemde atmosferden izole etme işlemidir. Potansiyel teknik depolama tesisleri petrol ve doğal gaz sahaları, kömür çıkarılamayan yer altı kömür ocakları, yer altı tuz ocakları gibi jeolojik depolama ya da okyanusların dibidir (Başaran, 2007: 446). İklim değişikliğine ilişkin çoğu senaryo çalışmasında karbon tutma ve depolamanın rolü artmaktadır. Uluslararası Enerji Ajansı (IEA), CCS teknolojileri yoluyla küresel karbondioksit salımlarının $\% 20$ düzeyinde en ekonomik şekilde azaltılabileceğini öngörmektedir. Söz konusu seviyeye ulaşılabilmesi için IEA, 2020 yllına kadar 100 ve 2050’ye kadar ise en az 3000 karbon yakalama tesisi kurulması gerektiğini savunmaktadır. Şu anda dünyada sadece 10 adet karbondioksit arıtma tesisi faaliyette olup, çoğunluğu Kuzey Amerika'da olmak üzere 28 adet karbon yakalama ve depolama tesisi yapım ya da planlama aşamasındadır (Taner, 2012: 2, 4). ${ }^{16}$ Karbon depolama yüksek maliyetli olmasına karşın, petrol şirketleri tarafından, tükenmekte ya

162009 yllında Amerika Birleşik Devletleri tarafından sağlanan 3 milyar dolarlık ekonomik teşvik paketi ile birlikte son yıllara kadar CCS teknolojileri büyük rağbet görmüştür. Projelerde maliyetlerin öngörülenden çok daha yüksek düzeylerde gerçekleşmesi bir sorun olarak durmaktadır (Taner, 2012: 2, 4). Ancak teknolojiye karşı duyulan endişelere rağmen örneğin, 1 milyar dolar tahsis edilen ve Norveç devlet girişimi Gassnova $(75.1 \%)$ ve Statoil (20\%), Shell (2.44\%) ve Güney Afrika Sasol (2.44\%) firmalarının katkılarılyla gerçekleştirilen dünyanın en büyük karbon yakalama teknoloji geliştirme ve deneme tesisi Mongstad 2013 yllında faaliyete geçmiştir (Statoil, 2018). 
da kısmen tükenmiş olan petrol kuyularından daha fazla ham petrol çıarmak için, sözü edilen kuyulara karbondioksit pompalanmak suretiyle üretim artış sağlanabilmektedir (Taner, 2012: 4). Bu durumda petrol sahalarına karbon depolama, daha fazla fosil yakıt elde etmenin bir yolu olarak kullanılmaktadır. Güncel analiz düzeyinin ve teknolojinin sinırlı olmasının yanı sıra çevresel etkiler, sızıntı riski vb. riskler de vardır.

\subsection{Enerji Adaleti ve İklim Adaleti}

Enerji üretimi ve tüketiminde gereken önemli değişikliklerin, bu geçişi yönlendirecek politik kararların iklim adaleti ve enerji adaleti üzerinde önemli etkileri olacaktır. Karbondioksit emisyonların 450 ppm düzeyinde stabilize etme ve $350 \mathrm{ppm}$ düzeyine indirme kararları bazı toplumları büyük risk altına sokacaktır. Bu geçişin bedelini kimin ödeyeceği bir adalet meselesidir (Newell and Mulyaney, 2013: 137) ve iklim değişikliği ve enerji politikalarındaki söz konusu değişme/değişmeme nedeniyle kaybedenler vardir.

Enerji adaletsizliği mevcut fosil yakıtlara bağımlı küresel ekonomi içinde zarar ve faydaların dağıtımını içermektedir. Bir tarafta enerji ve kalkınma, diğer tarafta karbon ve büyüme s1kı sıkıya bağlı durmaktadırlar (Newell and Mulyaney, 2013: 132). ABD'nin Kyoto Protokolü'nden çıkma gerekçelerinden biri karbondioksit emisyonu azaltımının ülke ekonomisine vereceği büyük zarardır. Karbondioksit emisyonunun sınırlandırılması, ABD vatandaşlarını iki şekilde etkileyebilir: Birincisi, karbondioksit emisyonuna sebebiyet veren enerji kullanımının sınırlandırılması ekonomik büyümeyi ve dolayısıyla yaşam kalitesini aşağı çeker (çevre hakkı-kalkınma hakk1 çatışması). İkincisi, emisyon sınırlaması gibi katı çevre standartları, ABD'nin rekabet üstünlügünü azaltır (adalet- ekonomik verimlilik çatışması) (Demirci, 2013: 186-187). Diğer tarafta ise uluslararası iklim değişikliği müzakerelerinde gelişmekte olan ülkelerin de kalkınma hakk1 ile küresel ekonomiyi karbonsuzlaştırma gereği arasında denge kurma çabaları, gelişmiş ülkelere "karbon borçlarını" ödeme ve "iklim adaleti" sağlama çağnıları yer bulmaktadır (Newell and Mulyaney, 2013: 136).

Ayrıca adalet sadece devletler arası bir sorun değildir; devletler içinde de sorun vardır. $\mathrm{Bu}$ tür tartışmalar dar gelişmiş-gelişmekte olan ülkeler karşıtllğından daha da karmaşıktır, çünkü sorumluluklar ve etkiler ülkeler içinde de kentsel/kırsal, zengin/yoksul, toplumsal cinsiyet, 1 rk ve sinıf açılarından eşitsiz bir şekilde dağılmıştır (Newell and Mulyaney, 2013: 136).

Enerji adaleti için önemli zorluklardan biri aynı anda enerji yoksulluğu ile iklim değişikliğinin nasıl uzlaştırılacağıdır. Uluslararası Enerji Ajansı'nın 2012 verilerine göre, dünyada elektriğe erişemeyen 1.6 milyar kişinin enerji adaleti sorununu da dikkate almak gerekecektir (Newell and Mulyaney, 2013: 132). Ayrıca bazı azaltım ve uyum önlemleri de bazı enerji hizmetleri için fiyatları 
yükseltir ve hizmete erişemeyen nüfusun enerjiye erişimini sağlama çabalarına ya da yoksulların hizmete erişimine zarar verebilir (IPCC, 2014: $30)$.

Enerji yoksulluğunu çözmeye yönelik çabalar zıtlıklarla doludur. Çin’in kömürden elektrik üretimine dayalı kalkınması yoksulların enerjiye erişimini artıracaktır, fakat bunun çevresel kalite ve iklim değişikliği açısından ciddi etkileri olacaktır. Üçboğaz Baraj1 (Three Gorges Dam) milyonlara enerji erişimi sağlamıştır, ancak mega proje nedeniyle yerinden edilen çevresel mülteciler gibi birçok sorun da ortaya çıkmıştır (Newell and Mulyaney, 2013: 136).

Sera gazı emisyonlarını artıran bazı mevcut teknolojilerin ve işlerin terk edilmesi nedeniyle iş kayıpları ortaya çıkabilecektir. Çin'de en son yayınlanan 13. Beş Yillı Plan enerji tüketimini azaltmaya çelik ve kömür sektörlerinden başladığından, bu sektörde çalışan 1,8 milyon çalışanın işine son verileceği açıklanmıştır (Pashley, 2016). Yenilenebilir teknolojiler devreye girdikçe kirlilik kontrolü, geri dönüşüm ya da yeni iş alanlarında istihdam olanağ1 artabilir. Ancak Giddens'ın (2013: 176) işaret ettiği gibi, yenilenebilir teknolojiler devreye girdikçe zamanla neredeyse tüm istihdam "bir avuç endüstriyel ülkede" toplaşacaktır.

Uluslararası düzeyde iklim değişikliği için ayrılan fonların kullanımında zıtlıklar görülebilmektedir. Dünya Bankası iklim fonlarının kullanımında çatışma açıktır. Güney Afrika'da kömürle çalışan Medupi enerji tesisinin inşaatında olduğu gibi, Banka enerji yoksulluğu ile mücadele etmek için küçük ölçekli yenilenebilir enerji projelerinden çok, büyük ölçekli altyap1 projelerini desteklemekte ve "temiz kömür" biçimlerini teşvik etmektedir. Eleştirilere göre, bu projelerden yoksul tüketiciler değil, büyük ölçekli endüstri faydalanmaktadır. "Temiz kömür" teknolojisi olarak adlandırılan teknoloji de karbon emisyonlarında bir miktar azalmaya imkan tanıabilir, ancak aynı miktar enerji için $\% 30$ daha fazla kömür kullanılmasını gerektirmektedir ve artan kömür talebinin kömür üreten topluluklar için ve Medupi kömür santralini besleyecek bir düzine maden için ve iklim için uzun vadeli farklı etkileri olmaktadır (Newell and Mulyaney, 2013: 137).

Enerji adaletinin sağlanması çabası güvenlik ve şiddetle ilgili sorunları da gündeme getirmektedir. Dünyada fosil yakıt kaynakları sıklıkla şiddet ve güvensizlikle iç içedir. Artan enerji maliyetleri ve ekonomik faaliyetler için enerji güvenliğini sağlama adına askeri güçler harekete geçirilir; Ortadoğu ve Kuzey Afrika'da görülen çatışmalar gibi. Bu ise bir "bumerang etkisi” yaratır; enerji tedariki için maliyetli askeri anlaşmalar, askeri harekâtlar ya da yükselen fiyatlar başkaları için adaletsizlikler yaratır (Newell and Mulyaney, 2013: 136). Devletler ya da devletlerin liderleri iklim değişikliğini kendi ulaşmak istedikleri amaçları doğrultusunda istismar edebilirler. Politik liderler iklim değişikliğinin yol açtı̆̆ı güçlükleri iç mücadeleler dahilinde ellerindeki 
iktidarı muhafaza etme ya da iktidarı ele geçirme amacıyla kullanabilirler. İklim değişikliği ile enerji kaynaklarının çakışmasının bir örneği Sudan'ın petrol ve minerallere sahip olması nedeniyle Çin'in ülkenin iç işlerine karışmasıdır (Giddens, 2013: 293-295).

Küresel enerji arz zincirlerinde enerji güvenliği ile insan hakları arasında çatışmalar ve zttlıklar vardır. Enerji ve doğal kaynaklardan zengin olan ülkeler ağırlıklı olarak ihracata bağlıdırlar. Michael Ross'un da dediği gibi, "petrolden zengin olan ülkelerin, petrolü olmayan ülkelere göre daha az demokrasisi, daha az ekonomik istikrarı ve daha sık sivil savaşları vardır." (Newell and Mulyaney, 2013: 136). Giddens'in (2013: 57) da işaret ettiği petrol lanetinde, petrolden elde edilen gelir ekonomik kalkınma süreçlerini tetiklemez. Oluşan zenginlik ya ülke dışına çıkar ya da yereldeki seçkinlerin elinde birikir. 1990'lardan itibaren öne sürülen ve "geleneksel kaynak laneti" olarak da adlandırılan bu duruma ek olarak günümüzde "kaynak lanetinin yeni yüzü" nün de çıtı̆ğı ifade edilmektedir. Buna göre, örneğin, Kanada önceki yönetimin ve iklim için harekete geçmek isteyen güçlü bir kamu desteğine karşın, kazançlı katran kumu endüstrisi için 2011'de Kyoto Protokolü'nden çekilmiştir. Avustralya ve ABD'de de doğal kaynak çıkarımına olan ekonomik ve siyasi bağımlılıkların demokratik katılım, kamu önceliklerinin desteklenmesi vb. sorunlar yarattığ1 ifade edilmektedir (Musolino ve Auth, 2014: 246, 250).

Giddens'a (2013: 76-77) göre, iklim değişikliğinin gizliden gizliye diğer meseleleri meşrulaştırmak için bir yol olarak kullanılması karşısında dikkatli olmak gerekir. Castree'nin (2011; Çoban vd., 2015: 402 vd) belirttiği gibi, yenilenebilir enerji elde etme çabasında yeni doğal kaynaklar sermaye birikim süreci içine girmektedir. Özelleştirme, ticarileştirme, kuralsızlaştırma, yeniden kurallaştırma, kamu sektörünü pazarın temsilcisi gibi kullanma, sivil toplumu devreye sokma ve bireyci etik araçları aracilığıla doğa neoliberalleștirilmektedir.

Düşük karbon ekonomisine geçişin sosyal ve çevresel sonuçları dikkate alınmadığında, karbonsuzlaştırma stratejileri benzer şekilde mevcut küresel ekonominin sömürü ve mülksüzleştirme modelleri ile karakterize edilebilebilir. "Temiz" (düşük karbon) teknolojileri de dahil olmak üzere teknolojik yenilik ve yeni birikim alanlarının araştırılması, adaletsizlik üretebilir. Tüm temiz teknolojilere homojen olarak "yeşil" gibi davranma eğilimi vardır. Ancak örneğin, güneş fotovoltaik teknolojiler zararlı kimyasallar, karmaşık küresel arz zincirleri ve fason üretim gerektiren teknolojilere dayanmaktadir (Newell and Mulyaney, 2013: 136). Hidroelektrik enerji üretme sürecinde de benzer örnekler vardır. Türkiye'de yerel halkın itirazlarına rağmen artan HES'ler temiz enerji elde etme ve iklim değişikliği ile mücadele aracı olarak kamunun meşruiyetini artırırken, piyasa mantığ1 ile işleyen süreçte hem kamusal araziler özel kullanıma açllmakta, 
hem de enerji piyasasında faaliyet gösteren özel şirketlerin desteklenmesini sağlamaktadır. ${ }^{17}$

İstikrarlı, ödenebilir ve güvenilir enerji kaynaklarına artan talep zengin ülkelerin ve çokuluslu şirketlerin arazi gaspında da etkilidir. Dünya Bankası büyük ölçekli arazi kamulaştırmalarını yoksullar için bir firsat olarak görürken, diğerleri (Harvey) mülksüzleştirme aracilığıyla birikim süreci olarak görmektedir (Newell and Mulyaney, 2013: 136). Biyoyakıtların gelişimi bu tür arazi gaspının aktif bir şekilde gerçekleştiği bir alandır; diğerlerinde de bu süreçler devam etmektedir. Örneğin, Meksika Oaxaca'da yerel topluluklar, büyük rüzgar enerjisi şirketlerinin yerel sakinlerin gereksinimlerine, arazi haklarına ya da kültürel mirasına fazla aldırmadan, kâr amaçlı geniş rüzgar çiftlikleri kurma planlarına direnmektedirler (Sweeney, 2014: 296). ABD'de son on yilda doğal gaz endüstrisi kaya gazı kaynakları için arazi elde ederken, Rusya kutuplarda enerji sınırını yeniden çizmektedir. Benzer şekilde otomobil endüstrisi, otomobillerin elektrifikasyonu için geniş lityum kaynaklarının olduğu Bolivya ya da Afganistan'da yeni yerler edinmektedir (Newell and Mulyaney, 2013: 136).

\section{Sonuç}

Kyoto Protokolü'ne sınırlı katılım ve 2009'da Kopenhag'da bir anlaşmaya varılamaması sonrasında Paris Anlaşması'nın kabul edilmesi, iklim değişikliği ile mücadelede yeni ve ümit verici bir aşama olarak görülmektedir. Paris Anlaşması, sanayi devriminden bugüne dünyanın ısınmasını $2 \mathrm{C}$ derecenin daha altında ve mümkün olduğunca $1.5 \mathrm{C}$ derecede sınırlandırmayı hedeflemektedir. Bu çerçevede ülkelerin temiz enerjiye hızlı bir şekilde geçmesi, küresel emisyonların hızlı bir şekilde azaltılması çağrısında bulunmaktadır. Paris Konferansı öncesinde ve konferans sırasında ülkeler, emisyon düzeylerini azaltma doğrultusunda ulusal katk1 beyanlarını

\footnotetext{
17 Türkiye'de enerji talebini karşılamak üzere hidroelektrik santrallerinin (HES) desteklenmesi ve teşvik edilmesi pratikte özel sektörün sürece ortak olmasının desteklenmesi ve teşvik edilmesi anlamına gelmektedir. Çünkü en önemli kamu kurumu olarak Devlet Su İşleri Genel Müdürlüğünün azaltılan bütçe kaynakları dikkate alındığında, anılan yatırımları gerçekleştirmek özel sektörden beklenmektedir. Bu durumda enerji hizmetinin sunulmasında kamu hizmeti gerekleri ile özel sektörün kâr elde etme hedefi çatışmalı bir şekilde bir araya gelmektedir. Planlama ve denetim aşamasında ortaya çıkan sorunlar, yer seçimi kararlarındaki sorunlar, arazi edinimi sırasında yapılan kamulaştırma ve acele kamulaştırma sorunları, aynı akarsuda ardı ardına birkaç santral yapılması, akarsu ölçeğinde bütünleşik planlama yapılmaması, çevresel etkilerin gereği gibi değerlendirilmemesi gibi nedenlerle birçok sorun ortaya çımaktadır. Bu durumda kamu yararı gözeterek doğru bir şekilde planlama ve denetim yapılmadığında, ticari kaygı ve piyasa mantığılla hareket edildiğinde, yenilenebilir enerji politika ve uygulamalarının birçok adaletsizlik yarattığ1 görülmektedir (Topçu, 2011; 239). Türkiye'de başta hidrolik enerji başta olmak üzere yenilenebilir enerji yatırımlarının olumsuz etkileri konusunda birçok çalışma yapılmış ve sorunlar dile getirilmiştir (Turhan vd., 2017; Topçu, 2011, 2015; Çağlar, 2014; Ürker ve Çobanoğlu, 2012; Kocak ve Balı, 2009; USİAD, 2010; Anter, 2015).
} 
sunmuşlardır. Ülkelerin verilen bu sözleri ne derecede tutacaklarını ve yeni kararlaştırılan büyük hedeflere ulaşıllp ulaşılmayacağını zaman gösterecektir. Çünkü söz konusu süreçte, ülkelerin enerji kaynaklarının kullanımının değişmesi ve/veya değişmemesi sadece iklim değişikliği ile ilgili taahhütlerle şekillenmemektedir. Ülkelerin genel ekonomileri içinde enerji politikaları belirleyici olmaktadır.

Ucuz enerji endüstriyel ekonomilerin motorudur ve tüketim kültürünün temelidir. Ekonomi, demokrasi (karbon demokrasisi) bol ve görece ucuz fosil yakıtlara bağımlıdır. Düşük karbon ekonomisine geçiş önerisinde, küresel fosil yakıt ekonomisinin yeniden yapılandırılmasında yoğun politik direnç ve kurumsal zorluklarla karşılaşlmaktadır. Bu nedenle sektörün ağırlığ1 ve politikaların belirlenmesi noktasında belirleyiciliği devam etmektedir. Sektör, enerji talebinin artması karşısında enerji güvenliğinin sağlanması ve ekonomik büyümenin devamı için doğrudan ya da sübvansiyonlar yoluyla dolaylı olarak desteklenmeye devam etmektedir.

Diğer yandan iklim değişikliği de kendi yeşil ekonomi, yeşil büyüme söylemini yaratmaktadır. Tarımsal ürünlere dayalı yakıtlar, nükleer enerji, karbon yakalama ve depolama teknolojileri, karbon ticareti, teknoloji, ürün ve hizmet patentleri, neoliberal ekonomi kurumları aracillğ1 ile kanalize edilen iklim finansmanı, temiz teknolojiler adı altında fosil yakıt temelli ve/veya çevresel ve sosyal etkisi fazla olan yenilenebilir teknolojilere sağlanan fon mekanizmaları öne çıkmaktadır.

$\mathrm{AB}$ düşük-karbon teknolojilerinin sağlayıcısı ve kullanıcısı olarak lider iken, ABD de temel bilimsel araştırma ve araştırmadan ürüne dönüşen teknolojik ilerlemede liderdir. Son y1llarda Çin teknoloji sunucusu olarak ortaya çıkmıştır ve güneş enerijisi gibi bazı alanlarda Avrupa'dan da ileridedir.

Gönüllü, piyasa temelli mekanizmalar, s1k1 düzenleyici kontrolleri önlemek için ortaya çıkmaktadır. Karbon vergileri emisyonlar üzerinde etkili olmaktan çok, hükümetlerin gelir elde etme yollarından biri olarak işlemektedir. Enerji sektörünün liberalleşmesi devam ederken, yeniden düzenleme sektör açısından piyasa koşullarının işleyişini bozacak risklerin giderilmesi işlevini üstlenmektedir. $\mathrm{Bu}$ nedenle yeşil ekonomi ekonomik büyüme ve çevresel koruma arasında bir "kazan-kazan" durumu tanımlasa da, kabul edilen önlemler en ılımlı olanlardır. Bunlar yükselen emisyonlarda beklenen azalmaya neden olmaz; aktörleri asgari önlemlerin ilerisine gitmeye zorlamaz. Bu yüzden küçük, kademeli değişikliklere yol açan yeşil ekonominin Paris'te öngörülen kısıtlamaları başarabilecek iklim yasalarını yaratması zor görünmektedir. Özellikle süreç içinde $A B D$ ve Çin gibi emisyonların yüksekliği dikkate alındığında, bağlayıcı ve kesin taahhütlerin olmaması bunu göstermektedir. 
Diğer yandan, insanlar ve yerler ne iklim değişikliğinin nedenlerinin ve sonuçlarının ne de enerjinin çıkarılması, üretimi, finansmanı, dağıtımı ve tüketiminin fayda ve maliyetlerini eşit bir şekilde yaşamaktadırlar. Düşük karbon ekonomisine geçişin sosyal ve çevresel sonuçları dikkate alınmadığında, karbonsuzlaştırma stratejileri de benzer şekilde mevcut küresel ekonominin sömürü ve mülksüzleştirme modellerini yeniden yaratmaktadır. Temiz (düşük karbon) teknolojileri de dahil olmak üzere teknolojik yenilik ve yeni enerji kaynakları için yeni alanların ele geçirilmesi adaletsizlik üretmektedir. Enerji yoksulluğu ve iklim değişikliği sorunları ile mücadele etmek için karşlıklı etkileşim dikkate alınmalı ve özellikle her iki sorun nedeniyle toplumun yoksul, kırsal, toplumsal cinsiyet, irk ve sinıf açısından yaşam alanları tehdit edilen hassas kesimleri gözetilmelidir. İklim değişikliği ve enerji politikalarının gerçek çözümlere erişebilmesi için öncelikle piyasa mantığının değiştirilmesi gerekmektedir. $A B D, A B$ ve Çin özelinde beklenen bu değişimin hem diğer gelişmiş ülkelerde hem de Hindistan, Türkiye, Meksika gibi enerji sorunlarının hızla arttığı gelişmekte olan ülkelerde sağlanması hayati önemdedir. 


\section{Kaynakça}

Ağaçayak, T., Nash, S. L., Şahin, Ü. (2017) İklim Politikalarnda Trump Etkisi: Küresel İklim Mücadelesinde Zor Zamanlar, İstanbul Politikalar Merkezi (IPM) ve Stiftung Mercator Girişimi, Nisan, İstanbul.

Akbaş, G. ve Apar, A. (2010) Avrupa 2020 Stratejisi: Akelll, Sürdürülebilir ve Kapsayicu Büyüme için Avrupa Stratejisi Özet Bilgi Notu, T.C.Başbakanlık Avrupa Birliği Genel Sekreterliği Sosyal, Bölgesel ve Yenilikçi Politikalar Başkanlı̆̆1, 14 Eylül, Ankara.

Akses, S. (2014) Avrupa 2020 Stratejisi, İktisadi Kalkınma Vakfi Yay, Nisan, İstanbul.

Algan, F. M. (2011) "Emisyon Ticareti Sistemini Kim Yönetiyor?", Mülkiye, Cilt:XXXV, S. 273, 81-107.

Anter, Y. (2015) "RES tepkisi tam gaz", 9 Mart, http://www.hurriyet.com.tr/ege/28394610.asp, (Erişim Tarihi 20.4.2015).

Avrupa Çevre Ajansı

https://www.eea.europa.eu/tr/isaretler/isaretler-2017-

avrupa2019da-enerjinin-gelecegini/makaleler/avrupa2019da-enerji2014-mevcut-durum, (Erişim Tarihi 6.5.2018).

Başaran, M. (2007) "Karbondioksit (CO2) Tutma ve Depolama" , TMMOB Türkiye VI. Enerji Sempozyumu - Küresel Enerji Politikalar ve Türkiye Gerceği, 442-456.

Bayraç, H. N. ve Çildir, M. (2017) “AB Yenilenebilir Enerji Politikalarının Ekonomik Büyüme Üzerindeki Etkisi”, Uluslararası Yönetim İktisat ve Issletme Dergisi, ICMEB17 Özel Sayısı, 201-212.

Bazilian, M., Outhred, H., Miller, A., Kimble, M. (2010) "Opinion: An energy policy approach to climate change", Energy for Sustainable Development, 14, 253-255.

Castree, N. (2011) "Neoliberalism and the Biophysical Environment 3: Putting Theory into Practice", Geography Compass, 5(1), 35-49.

Çağlar, Y. (2014) "Çevresel Etki Değerlendirmesi Bir Oyun Mudur? Ormanlar ve Ormancillk Üzerine Sessiz Tartısmalar", http://www.hidropolitikakademi.org/tr/ced-bir-oyun-mudur.html, s.1-15, (Erişim Tarihi 10.4.2015).

Çelikkol, H. ve Özkan, N. (2011) "Karbon Piyasaları ve Türkiye Perspektifi”, Dumlupinar Üniversitesi Sosyal Bilimler Dergisi, S.31, Aralik, 203-222. 
Çevre ve Orman Bakanlığ1 2008) Kyoto Protokolü Esneklik Mekanizmalar ve Diğer Uluslararast Emisyon Ticareti Sistemleri Özel İhtisas Komisyonu Raporu, Aralik.

Çevre ve Orman Bakanlı̆̆1 (2016) IKklim Değisikliği Karbon Proje ve Piyasası Terimler

S̈̈zlü̈ü̈,http://www.karbonkayit.cob.gov.tr/Karbon/Files/terimlers\%C3\%B6zl $\% \mathrm{C} 3 \% \mathrm{BCg} \% \mathrm{C} 3 \% \mathrm{BC}$.pdf, (Erişim Tarihi 5.1.2016).

Çiçek, H. G. ve Çiçek, S. (2012) "Karbon Vergisi İle Karbon Ticareti İzinlerinin Karşılaştırılması", İ.Ü. Siyasal Bilgiler Fakültesi Dergisi, N.47, Ekim, 95-119.

Çoban, A., Özlüer, F., Erensü, S. (2015) “Türkiye’de Doğanın Neoliberalleştirilmesi ve Bu Sürece Karşı Mücadeleler”, Yerel Yönetim Kent ve Ekoloji Can Hamamci'ya Armağan, (ed. A. Çoban), İmge Kitabevi Yay., 2015, Ankara, 399-456.

Değirmenci, E. (2007) "Yeşil Teknoloji ve İklimsel Adalet", Toplumsal Ekoloji, Kiş, S.5, 24-28.

Demirci, M. (2013) "İklim Değişikliği ve Dağıtıc1 Adalet”, Eskişehir Osmangazi Üniversitesi IIIBF Dergisi, Ekim, 8(2), 183-203.

Deutsche Welle (2015) "Yenilenebilir Enerjinin Yükselişi”, http://www.dw.com/tr/yenilenebilir-enerjinin-y $\% \mathrm{C} 3 \% \mathrm{BCkseli} \% \mathrm{C} 5 \% 9 \mathrm{Fi} / \mathrm{a}-$ 18525913, 18 Haziran, (Erişim Tarihi 11.1.2016).

Ekinci, F. ve Gönençgil, B. (2015) "Dünya Karbon Emisyon Piyasalarında Türkiye'nin Yeri” 6. Ulusal Hava Kirliliği ve Kontrolü Sempozyumu, http://www.hkk2015.org/bildiriler/bildiriler/068-081-EKINCI_Fulya.pdf, 7-9 Ekim 2015, İzmir, 68-81, (Erişim Tarihi 31.12.2015).

Engel, K. H. (2015) "EPA's Clean Power Plan: An Emerging New Cooperative Federalism?", Publius: The Journal of Federalism, Vol. 45, N.3, 452-474.

Geall, S. and Hilton, I. (2014) "Çin’in Çevresel Yönetişim Zorlukları", Dünyanın Durumu 2014, Worldwatch Enstitüsü, Türkiye İş Bankası Yay1n1, İstanbul, 177-188.

Giddens, A. (2013) Iklim Değ̌sisikliği Siyaseti, Phoenix Yay., (çev. E. Baltacı), Ankara.

Hahn, R. W. (2009) "Greenhouse Gas Auctions and Taxes: Some Political Economy Considerations", Review of Environmental Economics and Policy, V. 3, I. 2, Summer, 167-188.

Heras, B. P. D. L. (2013) "The European Union, The United States, and China Dialogue on Climate Change: Respective Policies and 
Mutual Synergies for a World Climate Order", The Georgetown International Environmental Law Review, Vol. 26, 13-46.

Hotunluoğlu, H. ve Tekeli, R. (2007) "Karbon Vergisinin Ekonomik Analizi ve Etkileri: Karbon Vergisinin Emisyon Azaltıc Etkisi Var Mi?”, Sosyoekonomi, Temmuz- Aralık, C. 6, S. 6, 107-126.

http://www.businessinsider.com/top-25-renewable-energy-companiesthomson-reuters-2017-11, 2017, (Erişim Tarihi 20.4.2018).

https: / /www.forbes.com/sites/rrapier/2016/03/30/the-worlds-largestpublic-oil-and-gas-companies/\#658169873173, 2016, (Erişim Tarihi 26.04.2018).

International Energy Agency- IEA (2015) World Energy Outlook Special Report Energy and Climate Change, Paris.

IPCC (2005) Special Report Carbon Dioxide Capture and Storage Summary for Policymakers A Special Report of Working Group III of the Intergovernmental Panel on Climate Change.

IPCC (2014) Climate Change 2014 Synthesis Report Summary for Policymakers, http://www.ipcc.ch/pdf/assessment-

report/ar5/syr/AR5_SYR_FINAL_SPM.pdf, (Erişim Tarihi 6.10.2015).

Karakaya, E. (2015) "Paris Anlaşması: İçeriği ve Türkiye Üzerine Bir Değerlendirme", http://www.sut-d.org/paris-anlasmasi-icerigi-veturkiye-uzerine-bir-degerlendirme/, (Erişim Tarihi 21.12.2015).

Kocak, M. ve Balı, A. (2009) "İşletmedeki HES Tesisleriyle İlgili Sorunlar ve Çözüm Önerileri”, http://www.dektmk.org.tr/pdf/enerji_kongresi_11/70.pdf, s.1-9, (Erişim Tarihi 28.4.2015).

Liu, L., Chen, C., Zhao, Y., Zhao, E. (2015) “China's carbon-emissions trading: Overview, challenges and future, Renewable and Sustainable Energy Reviews, 49, 254-266.

Mazlum, S. C. (2008) "Uluslararası İklim Politikası: Hakkaniyet ve Sürdürülebilirlik Ekseninde Bir Değerlendirme”, E. Karakaya (ed) Küresel Isinma ve Kyoto Protokolü: Íklim Değişikliğinin Bilimsel, Ekonomik ve Politik Analizi, İstanbul, Bağlam Yay., 129-167.

Musolino, E. and Auth, K. (2014) “İklim Yönetişimi ve Kaynakların Laneti”, Dünyanı Durumu 2014, Worldwatch Enstitüsü, Türkiye İş Bankas1 Yay1n, İstanbul, 245-257.

Newell, P. and Paterson, M. (2010) Climate Capitalism, Cambridge University Press, Cambridge. 
Newell, P. (2012) "The political economy of carbon markets: The CDM and other stories", Climate Policy, 12, 135-139.

Newell, P. and Mulvaney, D. (2013) “'The political economy of the cjust transition", The Geographical Journal, Vol. 179, No. 2, June, 132140.

Pashley, A. (2016) "Çin'in 5 yıllık planı karbon kesintilerinin artacağına işaret ediyor", (çev. Zeynep Şen) https://yesilgazete.org/blog/2016/04/02/cinin-5-yillik-planikarbon-kesintilerinin-artacagina-isaret-ediyor/, (Erişim Tarihi 3.5.2018).

Paterson, M. (2012) "Who and what are carbon markets for? Politics and the development of climate policy", Climate Policy, 12:1, 82-97.

Paterson, M. (2001) "Climate Policy as Accumulation Strategy: The Failure of COP6 and Emerging Trends in Climate Politics", Global Environmental Politics, 1 (2), 10-17.

Phelan, L., Henderson-Sellers, A., Taplin, R. (2013) "The Political Economy of Addressing the Climate Crisis in the Earth System: Undermining Perverse Resilience", New Political Economy, 18:2, 198226.

REN21 (Renewable Energy Policy Network fort he 21st Century), (2015) Renewables 2015 Global Status Report Key Findings, Paris, http://www.ren21.net/status-of-renewables/global-status-report/, (Erişim Tarihi 12.1.2016).

Statoil "Mongstad production facility, https://www.statoil.com/en/what-we-do/terminals-andrefineries/mongstad.html, (Erişim Tarihi 3.5.2018).

Sweeney, S. (2014) "Enerji Demokrasisine Doğru Çabalar", Dünyanm Durumu 2014, Worldwatch Enstitüsü, Türkiye İş Bankası Yayını, İstanbul, 291-308.

Taner, A. C. (2012) "Karbon Yakalama ve Depolama (Carbon Capture and Storage) CCS Teknolojisi Kapsamında Son Yapılan Küresel Bilimsel Araştırma ve Geliştirme (ARGE) Faaliyetleri”, http://www.fmo.org.tr/wp-content/uploads/2011/07/Karbon-Yakalama-veDepolama-Carbon-Capture-and-Storage-CCS-Teknolojisi-Kapsam\%C4\%B1ndaYap $\% C 4 \%$ B1lan-Son-Bilimsel-Ara $\% \mathrm{C} 5 \% 9 \mathrm{Ft} \% \mathrm{C} 4 \% \mathrm{~B} 1$ rma-ve-

Geli\%C5\%9Ftirme-ARGE-Faaliyetleri.pdf, s.1-6, (Erişim Tarihi 16.1.2016). 
Topçu, F. H. (2011) "Hidroelektrik Santrallarında Kamu ve Özel Sektörün Rolünün Değişimi ve Yarattığ Sorunlar", Uluslararası Alanya İsletme Fakiultesi Dergisi, C. 3, S. 3, s. 223-242.

Topçu, H. F., (2015) “Türkiye'de Yenilenebilir Enerji Üretimi ve Çevresel Etki Değerlendirmesi: Antalya Örneğinde Siyasal, Yönetsel ve Yargisal Bağlamda Bir Tartışma", Yerel Yönetim Kent ve Ekoloji Can Hamamciya Armağan, (ed. Aykut Çoban), İmge Kitabevi Yay., Ankara, s.229-267.

TP (Türkiye Petrolleri Strateji Geliştirme Daire Başkanllğı) (2016) Ham Petrol ve Doğal Gaz Sektör Raporu, May1s, http://www.enerji.gov.tr/File/?path=ROOT\%2F1\%2FDocument s\%2FSekt $\%$ C3\%B6r\%20Raporu\%2FTP_HAM_PETROL-

DOGAL_GAZ_SEKTOR_RAPORU_2015.pdf, (Erişim Tarihi 26.4.2018).

Turgut, M. (2015) “Türkiye'de Elektrik Endüstrisinde Deregülasyon Süreci ve Elektrik Borsasından Sürdürülebilir Beklentiler", Mubasebe ve Finansman Dergisi, Ekim, 99-112.

Turhan, E., Gündoğan, A. C., Aydın, C. İ., Berke, M. Ö. (2017) İklim Adaleti Mücadelesi İ̧in 10 Durak, Ekoloji Kolektifi Derneği, Haziran, Ankara.

Türkiye Enerji Vakfi (TENVA), (2018) “Avrupa Birliği’nin Enerji Dilemması" http://www.tenva.org/ab-yenilenebilir-enerjiyeyonelirken-dogu-avrupa-komurde-israrci/, (Erişim Tarihi 7.5.2018).

Türkiye İşveren Sendikaları Konfederasyonu (TiSK) ve Diğer Proje Ortaklar1 (2016), Herkes İ̧in Kurumsal Sosyal Sorumluluk Projesi Türkiye Sürdürülebilirlik Raporlaması Ulusal Inceleme Raporu, Şubat, Ankara.

UNFCC, http://unfccc.int/paris_agreement/items/9485.php, (Erişim Tarihi 15.11.2017).

USİAD (Ulusal Sanayici ve İşadamları Derneği) (2010) Hidroelektrik Enerji İcin Acil Durum Tespiti ve Öneriler, İstanbul.

Ürker, O. ve Çobanoğlu, N. (2012) 'Türkiye'de Hidroelektrik Santraller'in Durumu (HES'ler) ve Çevre Politikaları Bağlamında Değerlendirilmesi”, Ankyra: Ankara Üniversitesi Sosyal Bilimler Enstitüsü Dergisi, C.3, S.2, s. 65-88.

Vezirgiannidou, S. E. (2013) "Climate and energy policy in the United States: the battle of ideas", Environmental Politics, Vol. 22, No. 4, 593-609. 
World Bank (2015) State and Trends of Carbon Pricing, September, Washington DC.

World Resources Institute (2014) http://www.wri.org/blog/2014/11/6-graphsexplain-world\%E2\%80\%99s-top-10-emitters, (Erişim Tarihi 10.11.2015).

World Resources Institute (2016) CAIT Climate Data Explorer Paris Contributions Map, http://cait.wri.org/indc/, (Erişim Tarihi 10.01.2016).

World Resources Institute (2017) CAIT Climate Data Explorer Historical Emmissions

http://cait.wri.org/historical/Country\%20GHG\%20Emissions?in dicator $\llbracket=$ Total GHG Emissions Excluding Land-Use Change and Forestry\&indicator $\rrbracket=$ Total GHG Emissions Including Land-Use Change and Forestry\&year $]=2014 \&$ sortId $x=\mathrm{NaN} \&$ chart Type $=$ geo, $\quad($ Erişim Tarihi 15.11.2017). 